College of William \& Mary Law School William \& Mary Law School Scholarship Repository

2010

\title{
Monitoring the Convention on the Rights of Persons with Disabilities: Innovations, Lost Opportunities, and Future Potential
}

Michael Ashley Stein

Janet E. Lord

\section{Repository Citation}

Stein, Michael Ashley and Lord, Janet E., "Monitoring the Convention on the Rights of Persons with Disabilities: Innovations, Lost Opportunities, and Future Potential" (2010). Faculty Publications. 1101.

https://scholarship.law.wm.edu/facpubs/1101 


\title{
HUMAN RIGHTS QUARTERLY
}

\section{Monitoring the Convention on the Rights of Persons with Disabilities: Innovations, Lost Opportunities, and Future Potential}

\author{
Michael Ashley Stein* \& Janet E. Lord**
}

\begin{abstract}
As the first human rights treaty of the twenty-first century, the United Nations Convention on the Rights of Persons with Disabilities (CRPD) protects some 650 million persons with disabilities. The CRPD also has an opportunity
\end{abstract}

* Michael Ashley Stein holds a J.D. from Harvard Law School and a Ph.D. from Cambridge University. Currently the Executive Director of the Harvard Law School Project on Disability as well as Cabell Professor of Law at William \& Mary Law School, he has taught at Harvard, New York University and Stanford law schools. An internationally recognized disability rights expert, Professor Stein participated in the drafting of the United Nations Convention on the Rights of Persons with Disabilities and actively consults with international governments and national human rights institutions on their disability laws and policies. Professor Stein also acts as a legal advisor to Rehabilitation International and to the Special Olympics. Professor Stein is the recipient of various grants and awards and has been a fellow in both the East Asian Legal Studies Program and the Human Rights Program at Harvard Law School. Professor Stein's extensive scholarship has been published in various leading journals.

** Janet E. Lord is senior partner at BlueLaw International, LLP, a service-disabled, veteran-owned international law and development firm. A research associate at the Harvard Law School Project on Disability, she is an expert in international disability rights law and participated in the negotiation of the Convention on the Rights of Persons with Disabilities as legal advisor to Disabled Peoples' International and several lead governments. She has designed, managed, and implemented disability and development programs in more than twenty-five countries worldwide. She is currently Adjunct Professor of Law at the University of Maryland School of Law and has also taught courses in international law and international human rights at the University of Edinburgh, American University and the University of Baltimore School of Law. She holds an LL.M. from George Washington University Law School, a LL.M. and LL.B. from the University of Edinburgh in Scotland, and a BA from Kenyon College.

Our research was sponsored in part by a grant from Foundation Open Society (Zug). We thank Anne Bayefsky, Mara Bustelo, and Dinah Shelton for their comments; and Genevieve Jenkins and Lauren Hughes for their research assistance. For further information on the Harvard Law School Project on Disability, see www.hpod.org. 
to progressively reconfigure the structure and process of human rights oversight. While the overall framework for monitoring and implementing the CRPD resembles existing core human rights instruments, it has some notable features. The CPRD Committee is endowed with several innovations of significant potential, especially in the breadth of reporting and investigative procedures, thereby offering prospects for other treaty bodies and the human rights system more generally. Accordingly, this article examines the development of the CRPD Committee and assesses its potential for invigorating future United Nations monitoring reforms.

\section{INTRODUCTION}

As the first human rights treaty of the twenty-first century, the United Nations Convention on the Rights of Persons with Disabilities (CRPD or Convention) ${ }^{1}$ has an opportunity to progressively reconfigure the structure and process of human rights oversight. ${ }^{2}$ The Convention was opened for signature on 30 March 2007, and entered into force on 3 May 2008. ${ }^{3}$ On 3 November 2008, a monitoring Committee on the Rights of Persons with Disabilities (Committee) was elected during the initial Conference of States Parties ${ }^{4}$ to protect the rights of the world's largest minority, some 650 million persons with disabilities. ${ }^{5}$

The overall framework for monitoring and implementing the Convention resembles existing core human rights instruments, particularly the International Convention for the Protection of All Persons from Enforced Disappearance that was adopted eight days after the adoption of the CRPD. ${ }^{6}$ At the same time, the Committee is endowed with several notable innovations of significant potential, especially in the breadth of reporting and investigative

1. Convention on the Rights of Persons with Disabilities, adopted 13 Dec. 2006, G.A. Res. 61/106, U.N. GAOR, 61 st Sess., U.N. Doc. A/RES/61/106 (2006) (entered into force 3 May 2008) [hereinafter CRPD]. The CRPD text, along with its drafting history, resolutions, and updated list of signatories and states parties is posted on the United Nations Enable website, available at http://www.un.org/esa/socdev/enable/rights/convtexte.htm.

2. See id. The Convention was adopted by consensus by the General Assembly on 13 Dec. 2006, together with its Optional Protocol. Optional Protocol to the Convention on the Rights of Persons with Disabilities, adopted 13 Dec. 2006, G.A. Res.61/10, U.N. GAOR, $61^{\text {st }}$ Sess., U.N. Doc. A/RES/61/106 (2006) (entered into force 3 May 2008) [hereinafter CRPD Optional Protocol].

3. Notably, the CRPD received the most signatures on its initial day, is the second fastest ratified human rights treaty, and the fastest negotiated human rights treaty. See UN Enable, Factsheet on Persons with Disabilities [hereinafter UN Enable] available at http:// www.un.org/disabilities/default.asp?navid=13\&pid=150.

4. See CRPD, supra note 1, art. 34.

5 See UN Enable, supra note 3.

6. See International Convention for the Protection of All Persons from Enforced Disappearance, adopted 20 Dec. 2006, G.A. Res. 61/177, U.N. GAOR, 61 st Sess., U.N. Doc. A/ RES/61/177 (2007) [hereinafter Enforced Disappearances Convention]. 
procedures, thereby offering prospects for other treaty bodies and the human rights system more generally. ${ }^{7}$ Accordingly, this article examines the development of the CRPD Committee and assesses its potential for invigorating future United Nations monitoring reforms.

Part I of the article describes the Committee established by the United Nations to scrutinize the CRPD and highlights the Committee's advances over other human rights treaty bodies. Next, Part II looks at monitoring innovations that were suggested during the CRPD negotiations at a time when treaty body reform was a major subtext, but were not ultimately incorporated into the final instrument. In so doing, Part II considers how adoption of some of these oversight procedures could have affected broader human rights treaty reform efforts at the United Nations. Finally, Part III suggests creative avenues through which the Committee may yet progressively shape the direction of human rights treaty monitoring.

\section{THE CRPD COMMITTEE}

\section{A. Background to Proposals}

During negotiation sessions leading to adoption of the CRPD, a number of monitoring and implementation proposals were submitted to the Ad Hoc Committee responsible for negotiating the draft treaty. ${ }^{8}$ Consequently, the CRPD travaux préparatoires disclose a relatively wide range of viewpoints by states, Disabled Persons Organizations (DPOs), nongovernmental organiza-

7. For an exhaustive account of the Committee's processes, see Janet E. Lord \& Michael Ashley Stein, The Committee on the Rights of Persons with Disabilities, in THE UNITED Nations and Human Rights: A Critical Appraisal (Philip Alston \& Frédéric Mégret eds.) (forthcoming 2010).

8. See, e.g., Proposal on Monitoring Comprehensive and Integral International Convention on the Protection and Promotion of the Rights and Dignity of Persons with Disabilities, Asia Pacific Forum of National Human Rights Institutions, 6th Sess., Ad Hoc Comm. (2005) [hereinafter Asia Pacific Proposal] available at http://www.un.org/esa/socdev/enable/rights/ documents/ahc6nhrida25.doc; Comprehensive and Integral International Convention to Promote and Protect the Rights and Dignity of Persons with Disabilities, Working Paper by Mexico, U.N. GAOR, Ad Hoc Comm., 1st Sess., U.N. Doc. A/AC.265/WP.1 (2002) [hereinafter Mexico Proposal] available at http://www.un.org/esa/socdev/enable/rights/ adhocmeetaac265w1e.htm; see also Janet Lord \& Kathy Guernsey, Monitoring Symposium: A Contribution to the Formulation of Proposals for Monitoring a United Nations Convention on the Rights of People with Disabilities Report, U.S. National Council on Disability, American University, School of International Service \& Mental Disability Rights International (24 Oct. 2005) [hereinafter Monitoring Symposium Report](on file with authors); Katherine Guernsey, Janet Lord \& Kirsten Young, Ideas Memorandum on Implementation in Relation to a Convention on the Rights of Persons with Disabilities (Landmine Survivors Network, July, 2004)[hereinafter Ideas Memorandum](on file with authors). 
tions (NGOs), intergovernmental organizations (IGOs), and National Human Rights Institutions (NHRIs) on how an effective monitoring and implementation system could be developed for the Convention. ${ }^{9}$

The genesis of these innovative monitoring mechanisms was the general atmosphere of reform underway at the United Nations and a desire to respond to critiques of the current system of human rights treaty monitoring. ${ }^{10}$ Central among those concerns were overlapping and burdensome reporting obligations, backlogs in consideration of reports by treaty bodies, late submissions by states parties, and resource limitations. ${ }^{11}$ As a result, many

9. The CRPD travaux préparatoires may be found on the United Nations Enable website, available at http://www.un.org/disabilities/index.asp. In addition, several early proposals were put forward on monitoring prior to the convening of the 2004 Working Group. The Bangkok draft resulted from two regional workshops in Bangkok, Thailand in June and October of 2003 and was a comprehensive proposal insofar as it called for national level monitoring in addition to a treaty body with competence to receive reports, communications, and conduct inquiries, among other things. See Bangkok Draft: Proposed Elements of a Comprehensive and Integral International Convention to Promote and Protect the Rights of Persons with Disabilities, (2003), available at http://www.un.org/esa/ socdev/enable/rights/bangkokdraft.htm [hereinafter Bangkok Proposal]. The Chair's text presented before the convening of the Working Group offered two alternative models for implementation mechanisms, one proposing the establishment of (or use of existing) national human rights institutions to monitor Convention obligations, the establishment of a UN Disability Ombudsman, and reporting on disability issues to existing treaty bodies, and the other model mirroring existing treaty mechanisms by proposing the creation of a new treaty body which would monitor reports and receive communications and undertake inquiries. See Chair's Draft Elements of a Comprehensive and Integral International Convention on the Protection and Promotion of the Rights and Dignity of Persons with Disabilities, Draft Elements on Implementation: Application, Implementation and Monitoring of the Convention, 24 Dec. 2003, available at http://www.un.org/ esa/socdev/enable/rights/wgcontrib-chair2.htm [hereinafter Chair's Proposal]. Venezuela submitted an early proposal within the framework of its draft convention text based on the Mexico proposal, with some amendments. See Draft submitted by the Government of the Bolivarian Republic of Venezuela to the Secretary of the Ad Hoc Committee on a Comprehensive and Integral International Convention on the Protection and Promotion of the Rights and Disabilities, U.N. GAOR, U.N. Doc. A/AC.265/2003/WP.1 (18 June 2003), available at http://www.un.org/esa/socdev/enable/rights/a_ac265_2003_wp1.htm [hereinafter Venezuela Proposal].

10. See generally The Future of UN Human Rights Treaty Monitoring (Philip Alston \& James Crawford eds., 2000) [hereinafter Future OF UN]. Note that the first major discussion of reforming the human rights treaty body system occurred in 1989, with the release by the UN of a report on the subject by independent expert Philip Alston. See Effective Implementation of International Instruments on Human Rights, Including Reporting Obligations Under International Instruments on Human Rights, U.N. GAOR, 44th Sess., U.N. Doc. A/44/688 (1989) [hereinafter UN Initial Report]. A comprehensive bibliography of the voluminous literature on treaty body reform is set forth in a background paper to a major meeting on the topic. See Expert Workshop on Reform of United Nations Human Rights Treaty Monitoring Bodies, University of Nottingham Human Rights Law Centre Annex I (2006), available at http://www.nottingham.ac.uk/shared/shared_hrlcprojects/ Projects_Current_Projects_Nottingham_TB_Workshop_Report.pdf [hereinafter Nottingham Report].

11. As one commentator archly (but accurately) put it, the current system of monitoring processes "constitute some of the most powerless, under-funded, toothless, formulaic, 
CRPD drafters thought it would behoove a new treaty monitoring body to act as a test laboratory for intrepid processes. ${ }^{12}$

The Committee's origin thus reflects the struggle to establish an effective monitoring mechanism that avoided pitfalls of the current system. This tension served to delay negotiations on monitoring until the Ad Hoc Committee's penultimate session; ${ }^{13}$ in turn, the constricted time allotted to discussions encouraged a conservative result. ${ }^{14}$ Hence, although a number of the suggested

and politically manipulated institutions of the United Nations." Peter Uvin, Human Rights and Development 140 (2004). See also Claire O'Brien \& Michael O'Flaherty, Reform of UN Human Rights Treaty Monitoring Bodies: A Critique of the Concept Paper on the High Commissioner's Proposal for a Unified Standing Treaty Body, 7 Hum. Rts. L. Rev. 141, 144 (2007) ("To secure more than incremental improvements, it has been widely argued that the United Nations must radically redesign its treaty monitoring system. In particular, consolidation of the existing bodies, or at least of certain elements of their activities, has been urged.").

12. Two papers by the Office of the United Nations High Commissioner for Human Rights (OHCHR) provide an overview of treaty body reform and its implications for the CRPD. See Monitoring Implementation of the International Human Rights Instruments: An Overview of the Current Treaty Body System, U.N. OHCHR, Ad Hoc Comm. on a Comprehensive \& Integral Int'l Convention on Protection \& Promotion of the Rts. \& Dignity of Persons with Disabilities, 5th Sess., U.N. Doc. A/AC.265/2005/CRP.2 (2005) [hereinafter OHCHR Monitoring Overview] available at http://www.un.org/esa/socdev/ enable/rights/ahc5documents.htm; Expert Paper on Existing Monitoring Mechanisms, Possible Relevant Improvements and Possible Innovations in Monitoring Mechanisms, U.N. OHCHR, Ad Hoc Comm. on a Comprehensive \& Integral Int'l Convention on Protection \& Promotion of the Rts. \& Dignity of Persons with Disabilities, 7th Sess., U.N. Doc. A/AC.265/2006/CRP.4 (2006) [hereinafter OHCHR Expert Paper] available at http://www.un.org/esa/socdev/enable/rights/ahc7docs/ahc7unedchrmonitor.doc.

13. States caused additional delay by suggesting that any discussion of international-level monitoring would be premature until further progress was made on the outcome of treaty body reform. For an excellent discussion of the CRPD negotiations on monitoring, see Gerard Quinn, Resisting the 'Temptation of Elegance': Can the Convention on the Rights of Persons with Disabilities Socialise States in Rights Behaviour?, in THE UN Convention on the Rights of Persons with Disabilities: European and Scandinavian Perspectives 215, 224-229 (Oddný Mjöll Arnardóttir \& Gerard Quinn eds., 2009).The Working Group text, which laid the textual foundation of the CRPD, reflects this situation insofar as it includes a provision on national level monitoring, but only a footnote regarding international level monitoring. Draft Art. 25, Monitoring: National Implementation Framework Report,U.N. OHCHR, Ad Hoc Comm. on a Comprehensive \& Integral Int'I Convention on the Protection \& Promotion of the Rts. \& Dignity of Persons with Disabilities, U.N. Doc. A/AC.265/2004/WG/CRP.4/Add.1, Add.2, Add.4, Add.5 (2004) [hereinafter Working Group Draft] available at http://www.un.org/esa/socdev/enable/rights/ahcwgreporta25. $\mathrm{htm}$. Footnote 112 to the Working Group text reads as follows and is appended to the single provision on national level monitoring in the foundational CRPD text:

The Working Group did not have time to consider the issue of international monitoring of the draft Convention. Some members of the Working Group indicated, however, that international monitoring was an issue of considerable importance to them. Other members, however, had reservations in this respect.

14. The negotiation of the text on monitoring was essentially left to the Eighth and final negotiating session of the Ad Hoc Committee, with much work done intercessionally in the weeks leading up to that session, but no draft language existing as late as the Seventh. See Report of the Ad Hoc Committee on a Comprehensive and Integral International Convention on the Protection and Promotion of the Rights and Dignity 
reforms would have caused the Committee to diverge significantly from those of existing core treaties, ${ }^{15}$ the final form taken by the Convention's monitoring system resembles existing treaty bodies ${ }^{16}$ with some significant innovations culled from the tabled proposals. ${ }^{17}$ In its details, however, the monitoring provisions reflect the desire of the drafters to innovate towards the remediation of existing treaty body deficits and espouse many of the suggestions of the Office of the High Commissioner for Human Rights (OHCHR). ${ }^{18}$

\section{B. The Committee}

The Committee was initially constituted of twelve experts but the pace of state ratification allowed it to expand to its maximum authorized number of eighteen experts. ${ }^{19}$ The criteria for Committee experts, who serve in their

of Persons with Disabilities on its Seventh Session, U.N. GAOR, Ad Hoc Comm., 7th Sess., U.N. Doc. A/AC.265/2006/2 (2006), available at http://www.un.org/esa/socdev/ enable/rights/ahc7report-e.htm. It should be noted that Mexico tabled a "non-paper" at the Eighth Ad Hoc Committee meeting after being tasked with facilitating the discussion on monitoring and consolidating the various proposals into a document. See Non-Paper on Monitoring: Draft Elements for a Monitoring Mechanism of the International Convention on the Rights of Persons with Disabilities (15 June 2006), available at http://www. un.org/esa/socdev/enable/rights/ahc8docs/ahc8npmexico.doc.

15. The OHCHR website contains detailed information on the operation of the United Nations human rights treaty bodies, available at http://www.ohchr.org/EN/HRBODIES/ Pages/HumanRightsBodies.aspx.

16. See International Covenant on Civil and Political Rights, adopted 16 Dec. 1966, G.A. Res. 2200 (XXI), U.N. GAOR, 21st Sess., art. 41, U.N. Doc. A/6316 (1966), 999 U.N.T.S. 171 (entered into force 23 Mar. 1976) [hereinafter ICCPR]; Optional Protocol to the International Covenant on Civil and Political Rights, adopted 16 Dec. 1966, G.A. Res. 2200A (XXI), U.N. GAOR, 21st Sess., art. 5, U.N. Doc. A/6316 (1966), 999 U.N.T.S. 171 (entered into force 23 Mar. 1976) [hereinafter ICCPR Optional Protocol]; Convention Against Torture and Other Cruel, Inhuman or Degrading Treatment or Punishment, adopted 10 Dec. 1984, G.A. Res. 39/46, U.N. GAOR, 39th Sess., art. 17, U.N. Doc. A/39/51 (1985), 1465 U.N.T.S. 85 (entered into force 26 June 1987) [hereinafter CAT]; Optional Protocol to the Convention Against Torture and Other Cruel, Inhuman or Degrading Treatment or Punishment, adopted 18 Dec. 2002, G.A. Res. 57/199, art. 19, U.N. Doc. A/Res/57/199 (entered into force 22 June 2006) [hereinafter OPCAT]; Convention on the Elimination of All Forms of Discrimination Against Women, adopted 18 Dec. 1979, G.A. Res. 34/180, U.N. GAOR, 34th Sess., art. 17, U.N. Doc. A/34/46 (1980), 1249 U.N.T.S. 13 (entered into force 3 Sept. 1981) [hereinafter CEDAW]; International Convention on the Elimination of All Forms of Racial Discrimination, adopted 21 Dec. 1965, G.A. Res. 2106 (XX), U.N. GAOR, 20th Sess., art. 8, U.N. Doc. A/6014 (1966), 660 U.N.T.S. 195, (entered into force 4 Jan. 1969) [hereinafter CERD].

17. See infra, text at notes 69-82.

18. See OHCHR Monitoring Overview, supra note 12; OHCHR Expert Paper, supra note 12. We discuss the Committee's potential to innovate infra, Part III.

19. See CRPD, supra note 1, art. 34(2). Following an additional sixty states parties' ratifications, Committee membership can attain a maximum number of eighteen experts. See id. art. 34(2). For information concerning Committee membership, updated list of states parties as well as information on the first Conference of States Parties, see United Nations Enable website, available at http://www.un.org/esa/socdev/enable/rights/convtexte.htm. 
individual capacity, require a person to be competent, experienced, and possess high moral standing. ${ }^{20}$ Committee members are elected to four-year terms and are eligible once for re-election. ${ }^{21}$ Significantly, the incorporation of term limits is designed to ensure the vitality, impartiality, and independence of the Committee and respond to critiques that the absence of term limits in most treaty bodies compromises the long-term independence of the body and can serve to inhibit its dynamism. ${ }^{22}$

States parties are encouraged to consult closely with and actively involve persons with disabilities ${ }^{23}$ in nominating their own nationals for committee election at Conferences of States Parties ${ }^{24}$ and to give "due consideration" for representation by persons with disabilities on the monitoring body. ${ }^{25}$ This last provision is at variance with established practice and responds to concerns, common to marginalized groups, that only effective participation by experts bearing their group membership characteristics can ensure effective implementation of rights. ${ }^{26}$

The Committee's mandate in the context of disability parallels that of existing human rights treaty monitoring bodies. ${ }^{27}$ It is tasked with implementing the Convention's stated purpose "to promote, protect and ensure the full and equal enjoyment of all human rights and fundamental freedoms by all persons with disabilities, and to promote respect for their inherent

20. See CRPD, supra note 1 , art. 34(3).

21. See id. art. 34(7). One third of the originally elected experts were to have only two year terms, as selected by lottery.

22. The imposition of term limits was supported by the OHCHR and was also reflected in the Enforced Disappearances Convention that was concurrently under negotiation. See OHCHR Expert Paper, supra note 12, ฯ 17; Enforced Disappearances Convention, supra note 6 , pt. II, art. 26 , I 4.

23. See CRPD, supra note 1, art. 4(3).

24. See id. art. 34(5).

25. See id. art. 34(3).

26. See id.; cf. CEDAW, supra note 16, art. 17 ("experts of high moral standing and competence in the field covered by the Convention" shall "serve in their personal capacity, consideration being given to equitable geographical distribution and to the representation of the different forms of civilization as well as the principal legal systems"). Note, too, the progressive development of overall composition criteria as reflected in the requirement that consideration be given to balanced gender representation in both the Enforced Disappearances Convention, supra note 6, art. 26(1), as well as the OPCAT, supra note 16 , art. 5(4). It should be noted that proposals among some members of the disability community that the Committee be composed entirely of persons with disabilities, thereby underscoring the central importance of lived experience with disability, was not taken up by the Ad Hoc Committee, nor was the proposal that the Chair of the CRPD Committee be a person with a disability. It should be noted, however, that the composition of the first duly constituted Committee does indeed reflect cross-disability experience and expertise. For details as to the current membership of the CRPD Committee, see http://www.un.org/esa/socdev/enable/rights/convtexte.htm.

27. See especially Convention on the Rights of the Child, G.A. Res. 44/25, U.N. GAOR, 44th Sess., Supp. No. 49, at 166, U.N. Doc. A/44/49 (1989), arts. 43-45 [hereinafter $\mathrm{CRC}]$. 
dignity." ${ }^{28}$ As with other established human rights bodies, the Committee is empowered to pursue its agenda by monitoring reports of states parties, ${ }^{29}$ assessing information and shadow reports provided by DPOs and other interested non-state actors, ${ }^{30}$ issuing general comments and recommendations, and transmitting a biennial report to the General Assembly. ${ }^{31}$ Similarly, the Committee will establish its own procedural rules ${ }^{32}$ consistent with other treaty bodies ${ }^{33}$ and convene its initial meeting. ${ }^{34}$ The Secretary-General must provide the Committee with sufficient staffing and facilities to effectively perform its duties. ${ }^{35}$

\section{Innovations}

The final form taken by the Convention's monitoring system includes some of the more progressive core features suggested by the NHRI and Mexican proposals. ${ }^{36}$ Especially innovative for human rights treaties are provisions allowing the Committee to receive collective complaints, ${ }^{37}$ elicit the expertise and input of DPOs ${ }^{38}$ and UN specialized agencies and organs, ${ }^{39}$ and enact procedures to better manage reporting deadlines. ${ }^{40}$ The

28. See CRPD, supra note 1 , art. 1 .

29. See id. art. 35-37.

30. See id. art. 38(b).

31. See id. art. 39.

32. Id. art. 34(10).

33. See, e.g., CRC, supra note 27 , art. 43(8). OHCHR has noted the drawbacks associated with the ad hoc development of rules of procedures among the various treaty bodies that had led to variations in practice that can be confusing to states and other actors within the system and that some level of coordination could enhance working methods and coherency of the system. OHCHR Monitoring Overview, supra note 12, 44.

34. The first Committee meeting was convened in Geneva on February 23, 2009. Information on the first session is available at http://www.ohchr.org/EN/HRBodies/CRPD/Pages/ Session1.aspx.

35. Monitoring Overview, supra note 12, art. 34(11).

36. See Asia Pacific Proposal, supra note 8; Mexico Proposal, supra note 8. The NHRIs may be credited with proposing a Committee empowered to receive collective complaints by and on behalf of individuals with disabilities, and to proactively inquire into the situation of persons with disabilities. Clearly traceable to the original Mexico proposal are a Committee with traditional reporting obligations as well as communications and inquiry procedures housed separately in the Optional Protocol. So, too, is the provision on Conferences of States Parties which, although it manifested in a more condensed form, is a key innovation in human rights conventions.

37. CRPD Optional Protocol, supra note 2, art. 1(1).

38. See CRPD, supra note 1, art. 4(3) (making consultations with disabled persons and their representative organizations a general obligation); Id. art. 33(3) (requiring states parties to include civil society in the monitoring process at the national level); Id. arts. 34(3), 35(4) (calling on states parties to consider consultations with NGOs in the formulation of Committee member nominations as well as in the preparation of reports).

39. See id. art. 38(a).

40. See id. art. 36(2). 
provision convening a periodic Conference of States Parties to consider implementation matters is likewise a novelty. ${ }^{41}$

\section{Collective Complaints}

The Committee is authorized to accept and deliberate upon individual and group communications regarding alleged violations of the CRPD ${ }^{42}$ asserted against states parties to the Optional Protocol. ${ }^{43}$ Communications may also be submitted on behalf of aggrieved individuals, thereby implying the involvement of DPOs, NGOs, and other advocates in advancing claims. ${ }^{44}$ Otherwise, the admissibility of communications mirrors that of other international complaints procedures. ${ }^{45}$ Likewise, the Committee may at any time after receiving a communication but before determining its merits, request a state party to adopt sufficient interim measures "to avoid possible irreparable damage" to the alleged victims of its actions. ${ }^{46}$ The Committee's request, however, does not imply the ultimate admissibility or merits of the given communication. ${ }^{47}$ Communication procedures are confidential and issued recommendations are not enforceable. ${ }^{48}$

\section{DPO Participation}

The participation of persons with disabilities and DPOs in Conventionrelated monitoring and implementation at all levels is both implicitly ${ }^{49}$ and explicitly woven throughout the entire fabric of the text. ${ }^{50}$ DPO participation is implicitly provided for in the monitoring process insofar as states parties are directed to consider consultations with civil society in the formulation of Committee member nominations ${ }^{51}$ as well as in the preparation of their

41. See id. art. 40.

42. See CRPD Optional Protocol, supra note 2, art. 1(1).

43. See id. art. 1(2).

44. See id. art. 1(1).

45. Communications are inadmissible when made anonymously, when the underlying events occurred before the relevant state party ratified the Optional Protocol and did not continue after that time, when the "same matter" has been considered previously by the Committee or is currently under review "under another procedure of international investigation or settlement," where the complainant has failed to exhaust domestic remedies (unless these can be shown as unreasonably obfuscatory or inefficacious), where the communication is unfounded or unsubstantiated, or where it abuses the right to submit under, or conflicts with, the CRPD's provisions. See id. art. 2(a)-(f).

46. Id. art. 4(1).

47. See id. art. 4(2).

48. See id. art. 5 .

49. Implicit participation is created through the vehicle of the general obligation, and the general principles of participation and inclusion. See id.

50. See generally Michael A. Stein \& Janet E. Lord, Jacobus tenBroek, Participatory Justice, and the UN Convention on the Rights of Persons with Disabilities, 13 TEx. J. C.L. \& C.R. 167 (2008) (discussing the participatory justice dynamic of the convention).

51. CRPD, supra note 1, art. 34(3). 
reports. ${ }^{52}$ These features together represent perhaps one of the most progressive developments in human rights law provided by the CRPD (even if stakeholder input is at times informally encouraged by other treaty bodies). ${ }^{53}$ It reflects the fundamental principle that the persons most affected have the right to participate in decisions that impact them. In the disability context more specifically, it represents a sharp turn from marginalization and lack of voice in decisional processes. Moreover, the experience of the $\mathrm{Ad} \mathrm{Hoc}$ Committee sessions demonstrates that including the targeted group facilitated negotiations by educating states representatives about these individuals as well as lending credibility to the substance of the treaty. ${ }^{54}$

\section{Input from UN Specialized Agencies and Organs}

To foment effective implementation of the CRPD, including international cooperation, the Committee is authorized to consult with "other relevant bodies instituted by international human rights treaties." ${ }^{15}$ In particular, it envisages that the Committee will have due regard to the work of other treaty bodies whose work will necessarily overlap with it and also take into account the on-going interest in ensuring that the reporting process is meaningful without being duplicative..$^{56}$ The Committee is also encouraged to cooperate with United Nations specialized agencies and other organs. ${ }^{57}$ These in turn are "entitled to be represented" during CRPD implementation, ${ }^{58}$ which would include not only the reporting process but also Conferences of States Parties; moreover, they may be invited by the Committee to share technical assistance and to submit reports. ${ }^{59}$ Such bodies are a potentially important resource for the Committee to tap into in order to effectively fulfill its mandate. Some of the specialized agencies possess considerable expertise in relation to particular issue areas covered by the Convention.

52. Id. art. 35(4).

53. Id. art. 4(3) (referencing the important role of persons with disabilities and their representative organizations in the development and implementation of legislation and policies that give effect to the CRPD).

54. For more on the role of DPO participation in the CRPD drafting process and voice accountability, see Janet E. Lord, Disability Rights and the Human Rights Mainstream: Reluctant Gatecrashers?, in The International Struggle for New Human Rights (Clifford Bob ed., 2009). See also Janet E. Lord, Mirror, Mirror on the Wall: Voice Accountability and NGOs in Human Rights Standard Setting, 5 Seton Hall J. Dipl. \& Int'L Rel. 93 (2004).

55. See CRPD, supra note 1 , art. 38(b).

56. The rationale for such inclusion by the CRPD is "with a view to ensuring the consistency of their respective reporting guidelines, suggestions and general recommendations, and avoiding duplication and overlap in the performance of their functions." See id.

57. Id. art. 38 .

58. Id. art. 38(a).

59. Id. 


\section{Reporting Deadlines}

Within two years of the Convention entering into force (3 May 2008), each state party must submit to the Committee via the Secretary-General "a comprehensive report on measures taken to give effect to its [CRPD] obligations," ${ }^{\prime \prime 0}$ and may also identify impediments to fulfilling those obligations. ${ }^{61}$ Subsequently, states parties must submit reports on at least a quadrennial basis. ${ }^{62}$ The Committee is given the flexibility to request more frequent reports, which is distinct among human rights conventions negotiated prior to the CRPD. ${ }^{63}$ The Committee's power to prescribe content guidelines makes explicit a practice that has developed over time and has been particularly effective in the context of the Convention on the Rights of the Child. ${ }^{64}$ The role of the Committee in articulating reporting guidelines is a particularly important one and the Committee should take up the challenge to follow the best practices of existing treaty body practice in formulating and progressively developing over time its guidelines ${ }^{65}$ When appropriate the Committee may disseminate reports, along with its observations, recommendations, and requests for technical assistance or advice, to United Nations specialized entities "and other competent bodies." 66

\section{Conference of States Parties}

CRPD Article 40 provides for periodic meetings of state parties to assess the implementation of the treaty, and is thus unique among core human rights conventions. ${ }^{67}$ While previous human rights conventions reference meetings of states parties, these mechanisms are intended to be used for limited

60. Id. art. 35(1).

61. Id. art. 35(5).

62. Id. art. 35(2).

63. For more on discretion in the context of treaty body reporting periodicity, see OHCHR Monitoring Overview, supra note 12, 916 . The Human Rights Committee has adopted similar procedures, although it has yet to implement them.

64. CRPD, supra note 1, art. 35(3). The CRC Committee is particularly notable for its detailed Guidelines and its novel grouping of CRC provisions in those Guidelines in thematic clusters to facilitate state parties in their reporting efforts. See General Guidelines regarding the Form and Contents of Initial Reports U.N. Doc. CRC/C/5, 30 Oct. 1991, available at http://www.un.org/depts/dhl/resguide/spechr.htm; General Guidelines regarding the Form and Content of Periodic Reports, U.N. Doc. CRC/C/58 (11 Oct. 1996), available at http://www1.umn.edu/humanrts/instree/guidelines.htm.

65. Guidelines on reporting "are designed to ensure that reports are presented in a uniform manner so that [the treaty body] can obtain a complete picture of the situation of implementation." OHCHR Expert Paper, supra note 12, at - 33. For a thorough account of reporting under existing bodies and suggestions directly pertaining to the formulation of reporting procedures under the CRPD, see OHCHR Monitoring Overview, supra note 12 , ๆ $20-40$.

66. CRPD, supra note 1, arts. 36(5), 38(a).

67. See id. art 40. For a discussion of Conferences of States Parties within the context of the CRPD negotiations, see OHCHR Expert Paper, supra note 12, ๆ ๆ 65-66. 
purposes pertaining to the election of Committee members or amendments and not for the broader purpose envisioned by the drafters of the CRPD. ${ }^{68}$ Instead, the Conference of States Parties introduced by the Convention more closely approximate those seen in international environmental or arms control contexts. ${ }^{69}$ This is because they are meant to facilitate implementation by drawing together a wide range of actors, including states parties, relevant United Nations agencies, DPOs, NGOs, and others to provide a forum for discussion and reflection on how to best operationalize the Convention. ${ }^{70}$ Consensus by the states parties on politically charged issues might obviate the type of criticisms lodged against the Human Rights Committee that it stretched its mandate by claiming implied powers.

\section{ALTERNATIVE CRPD MONITORING PROPOSALS}

Negotiation of the CRPD offered the prospect for developing an innovative monitoring scheme that departed significantly from standard human rights monitoring approaches, and significant innovations were incorporated. Nevertheless, because the monitoring debate was deferred until the last Ad Hoc session, when strong concerns arose about concluding the negotiations before consensus unraveled, in the end creativity gave way to expediency. ${ }^{71}$ One might take the view that this is water under the bridge, and yet it stands to reason that alternative proposals floated during the CRPD negotiations could well inform ongoing dialogue on monitoring in continuing discussions on human rights treaty body reform. Accordingly, the discussion that follows highlights some of the key alterative options put forward during CRPD negotiations, while Part IV offers suggestions on how such innovations could yet be realized.

\section{A. The Ad Hoc Drafters as Agents of Change}

The drafters of the CRPD understood that the vast majority of states did not have comprehensive disability legislation. Further, drafters recognized that

68. The Mexican draft convention text was the first to include the broad conceptualization of the Conference of States Parties. See Mexico Proposal, supra note 8.

69. See, e.g., Convention on the Prohibition of the Use, Stockpiling, Production and Transfer of Anti-personnel Mines and on Their Destruction, adopted 18 Sept. 1997, art. 11, 2056 U.N.T.S. 211 (entered into force 1 Mar. 1999) [hereinafter Mine Ban Treaty] available at http://treaties.un.org/Pages/Treaties.aspx?id=26\&subid=A\&lang=en.

70. See CRPD, supra note 1 , art. 40.

71. One might note that a similar dynamic existed in 1984 during negotiations of the Convention against Torture, whose deliberations were influenced by Western states seeking quick adoption and communist states wishing weaker implementation mechanisms. 
all too often existing legislation was very narrow in scope and reflected a medical/charity model rather than a rights-based approach to disability. ${ }^{72}$ It was thus readily acknowledged that a new monitoring mechanism must do more than monitor existing laws. It must be equipped to provide technical assistance to states in the development of new legislation and, where applicable, in improving and enforcing existing legislation in line with the CRPD. Relatedly, and somewhat unlike the situation with other marginalized groups such as women, children, and racial minorities, most states do not have anything approaching reliable statistics and data of populations of person with disabilities. Statistical information is considered fundamental for supporting implementation. Lack of empirically verifiable data helped stimulate the idea that a monitoring mechanism should contribute to the creation of accurate in-country databases that in turn could enhance the capacity of states to craft responsive public policies.

Finally, a new monitoring mechanism was regarded as a core component of addressing gaps caused by the lack of engagement by existing treaty bodies in disability rights issues coupled with the non-participation of DPOs in the UN human rights system in any sustained way. Some of the proposals tabled before the Ad Hoc Committee, but ultimately not taken up or reflected in the final text in their entirety, sought to help transform the existing system of monitoring and implementation into a more proactive and robust framework. Should these be acted upon, either through formal UN reform or (more likely) procedurally by the Committee, they can help reshape human rights treaty monitoring and implementation in a progressive direction.

\section{B. National Action Plans and NHRI Advocacy on Monitoring}

One of the more comprehensive and creative schemes for monitoring the future treaty was suggested at the sixth Ad Hoc Committee session by the Asia Pacific Forum of National Human Rights Institutions ${ }^{73}$ and taken up with enthusiasm by experts who convened to consider monitoring approaches. ${ }^{74}$

72. See Michael Ashley Stein \& Penelope J. S. Stein, Beyond Disability Civil Rights, 58 HASTINGS L. J. 1203, 1203 (2007). ("Unfortunately, the continuing economic inequities and social exclusion of disabled persons worldwide severely calls into doubt the efficacy of these efforts. It also begs the question of whether any country adequately protects its disabled citizens.")

73. See Asia Pacific Proposal, supra note 8. Many of the ideas reflected in the proposals put forward by NHRIs were first put forward at a conference convened by the Harvard Law School Project on Disability, at Harvard Law School, in advance of the Sixth Session of the Ad Hoc Committee.

74. The Asia Pacific Proposal also included guidelines for rigorous national level implementation. Asia Pacific Proposal, supra note 8, arts. 25bis-27, 31-33. A number of other proposals emphasized the role of national level monitoring. For a compilation of these 
The NHRIs proposed an international monitoring body comprised of a majority of persons with disabilities ${ }^{75}$ that would consult with $\mathrm{DPOs}^{76}$ and be assisted in its duties by a global disability rights advocate. ${ }^{77}$ The proposed committee would have been able to examine the situation of persons with disabilities by receiving collective complaints, ${ }^{78}$ by applying its own proactive inquiries, ${ }^{79}$ and through regional assessments. ${ }^{80}$

A particularly far-reaching innovation required states parties to submit national action plans, which are a core feature of disability rights implementation in Australia and heavily touted by Australian NHRI and NGO representatives. ${ }^{81}$ The rationale for this proposal was the view that national action plans can serve as an anchor for monitoring compliance with obligations. The process by which national action plans are developed triggers governments to think of how they will implement and what priorities they have given their own situation. ${ }^{82}$ Thus, under this mechanism, development of the plans could have provided a centerpiece for monitoring; completed plans might have provided guidance for a treaty monitoring body in an individualized examination of treaty implementation by a state party. An additional advantage is that the explicit incorporation of national level planning within the framework of the CRPD could help to shift the focus of implementation away from the singular focus on reporting. ${ }^{83}$

proposals from governments, NGOs and NHRIs pertaining to national-level monitoring and implementation, see Compilation of Proposals on a Monitoring Mechanism for an International Convention on the Rights of Persons with Disabilities 53-59 (12 May 2006) [hereinafter Compilation of Proposals] available at http://www.un.org/esa/socdev/enable/ documents/mntrng_cmpltn.doc; see also Monitoring Symposium Report, supra note 8.

75. Asia Pacific Proposal, supra note 8, art. 28(2)(a).

76. Id. art. 34.

77. Id. arts. 38-39.

78. Id. art. 45.

79. Id. art. 38.

80. Id. art. 37.

81. The NHRI proposal was inspired by a number of NGO proposals, including the report on the national consultations held in Australia and spearheaded by People with Disability Australia. See Comprehensive and Integral International Convention on the Rights of Persons with Disabilities, Report on National Consultations (People with Disability Australia, Australian Federation of Disability Organizations, National Association of Community Legal Centers 79) (Aug. 2004), available at http://www.pwd.org.au/disabilityconvention/ convention_consult_report.doc. The Australian NGO report was instrumental in calling for the development, implementation and evaluation of progressive national action plans to facilitate implementation of treaty obligations. $I d$. 4.26 .

82. For instance, national action plans cause developing countries, countries with federal/ provincial systems, or countries looking to progressively realize economic, social and cultural rights, to consider how to allocate their resources.

83. Compare Philip Alston, Richard Lillich Memorial Lecture: Promoting the Accountability of Members of the Human Rights Council, 15 J. Transnat'L L. \& Pol'Y 49, 62 (2005) (“Under most of the core treaties, States Parties are required to make an initial report within 2 years and then to provide additional or 'periodic' reports every four or five years thereafter. Compliance with the obligation to report is central to the accountability mechanisms 
Given the emergence of national human rights action planning as a core strategy of NHRIs, ${ }^{84}$ the explicit mention of action plans within the context of national-level implementation of the CRPD could have underscored the role of those institutions in securing disability inclusion. As it stands, absent any explicit language to this effect, it will be up to governments, DPOs, and NHRIs acting on their own initiative to integrate disability rights into national human rights action plan monitoring schemes or to foster disability-specific human rights action planning. The Committee may yet take up this idea and make it part and parcel of its iterative communication with states parties in the reporting process. More helpfully, perhaps, would be the role that the Committee could play in providing specific guidance on disability-specific action planning in the form of a general comment.

Finally, it should be noted that treaty reform dialogue has generated some ideas for strengthening the role of NHRIs in treaty body processes, again, issues that could have been taken up by the CRPD drafters. ${ }^{85}$ Moreover, several of the treaty bodies have issued general comments concerning the role of NHRIs. The potential for cross-fertilization has yet to be realized. ${ }^{86}$

\section{Other Treaty Body Reporting Innovations}

The production of a report to a treaty body is intended to generate a dialogue within civil society about the requirements of the treaty, the application of the standards to local conditions, the shortfalls in compliance, priorities for

established under these treaties."), with Jo M. Pasqualucci, The Right to a Dignified Life (Vide Digna): The Integration of Economic and Social Rights with Civil and Political Rights in the Inter-American Human Rights System, 31 Hastings INT'L \& Comp. L. Rev. 1, 12 (2008).

Human rights treaties require that the signatory states ensure the rights protected to all persons without discrimination. Within this context, the American Convention and other human rights instruments specifically prohibit States from discriminating against persons on the basis of their 'economic status.' States must protect and ensure the human rights of those subject to their jurisdiction whether they are poor or rich.

84. On national human rights action plans generally, see U.N. OHCHR, HANDBOOK ON NAtional Human Rights Plans of Action (2002), available at http://www.ohchr.org/Documents/ Publications/training10en.pdf.

85. See, e.g., Amnesty International, United Nations Proposals to Strengthen the Human Rights Treaty Bodies (Sept. 1, 2003), AI Index, IOR 40/018/2003, available at http:// asiapacific.amnesty.org/library/Index/ENGIOR400182003?open\&of=ENG-375.

86. See The Role of National Human Rights Institutions in the Protection of Economic, Social and Cultural Rights, General Comment No. 10, U.N. ESCOR, Comm. on Econ., Soc. \& Cult. Rts., 19th Sess., U.N. Doc. E/1999/22 at 18 (1998); Establishment of National Institutions to Facilitate Implementation of the Convention, General Recommendation No. 17, Comm. on the Elim. of Racial Discrim., U.N. GAOR, 42nd Sess., U.N. Doc. A/48/18 (1993); The Role of Independent National Human Rights Institutions in the Promotion and Protection of the Rights of the Child, General Comment No.2, U.N. GAOR, Comm. on Rts. of the Child, 32nd Sess., U.N. Doc. CRC/CG/2002/2 (2002). 
redress, and the design of a plan of action. ${ }^{87} \mathrm{~A}$ cycle of pre-report consultation followed by post-report planning at the national level is supposed to be created via the periodic drafting of state reports. ${ }^{88}$ In practice this national-level planning has not always happened. Instead, report drafting, often done in backrooms without stakeholder engagement, has become the chief focus of national-level activity in connection with the human rights treaty reporting system. ${ }^{89}$ The NHRI proposal for national action plans was in part a response to this weakness in the traditional treaty body reporting process. Other proposals were put forward to tackle this issue, drawing in part on practices that have evolved in other international law contexts. ${ }^{90}$

One of the more creative ideas originated in an informal request by Costa Rica for experts to look carefully at possible alternatives to the standard treaty body reporting schemes. Consequently, the Regional Group for Latin America and the Caribbean (GRULAC) through the Costa Rican Permanent Mission commissioned a paper ${ }^{91}$ on monitoring, that, among other things, suggested that the monitoring system utilized by the International Monetary Fund (IMF) ${ }^{92}$ was worthy of study and adaptation. The IMF utilizes a thematic, targeted approach that includes visitation by experts and constructive dialogue with the state under review, rather than traditional state-based reporting. ${ }^{93}$ Under this approach, a treaty body might conduct a certain number of reports within each region per year and would be able to call for more targeted reporting in place of periodic reporting at fixed intervals. ${ }^{94}$ Under this "reverse reporting" system, an entity other than the state under scrutiny prepares a report reviewing compliance commitments, based on

87. See Future of UN, supra note 10.

88. CRPD, supra note 1, arts. 35(2), 36.

89. See Future of UN, supra note 10.

90. See, e.g., Monitoring Symposium Report, supra note 8.

91. See Janet E. Lord \& Katherine N. Guernsey, Checklist for the Formulation of Government Positions on Monitoring 2 (July 2005) (on file with authors).

92. See International Monetary Fund \& World Bank, Strengthening Debt Management Practices_Lessons from Country Experiences and Issues Going Forward: Background Paper 3 (2007), available at http://www.imf.org/external/np/pp/2007/eng/032707b.pdf.

The process of moving from a set of general principles to a program of concrete reforms and capacity building in a particular country is not straightforward. Recognizing this, a joint World Bank and IMF pilot program including 12 countries was initiated in 2002, with the objective of assisting countries in designing and implementing reforms with corresponding capacity building of the areas of [public debt management] and domestic government debt market development.

93. Under this process, states have the opportunity to respond to the expert-driven critique. See id. at 5 .

Elements that bring about sustained reform included . . . [i]ntegrating the debt management reform process into broader programs, such as public sector or public financial management reforms. One benefit to this approach is that it helps ensure project sustainability and continuity through financing, support by experts, and project supervision.

94. For discussion of the periodicity of the current reporting process, see OHCHR Monitoring Overview, supra note 12 , ๆ 14 \& tbl.2. 
dialogue between the reviewing body and the government concerned. In this way, monitoring moves beyond self-reporting and self-certification to forms of external monitoring.

A group of experts convened at the American University, School of International Service, took this line of research farther and studied other types of peer review or "reverse reporting" mechanisms..$^{95}$ Models noted for possible adaptation in a human rights context included the system adopted by the World Trade Organization by its Trade Policy Review Body ${ }^{96}$ and the OECD peer review system. ${ }^{97}$ This system of peer review mechanisms received attention in the OHCHR report on monitoring options for the CRPD. ${ }^{98}$ Such an approach might well have facilitated a deeper level of exchange, something the drafters recognized as important in the context of a complex and comprehensive treaty cutting across so many issues. Thus, for example, in international law contexts where peer review is used, it can serve to check compliance or, alternatively, to facilitate implementation by establishing a cooperative framework. In the nuclear safety context, peer review is used in two ways. The International Atomic Energy Agency (IAEA), the World Association of Nuclear Operators (WANO), and the Institute of Nuclear Power Operations (INPO) utilize peer review in their safety review services, which involve the technical, on-site review of nuclear installations by nuclear plant operators. ${ }^{99}$ Another approach is embodied in the Convention on Nuclear Safety ${ }^{100}$ designed to monitor state compliance with the provisions of the treaty. ${ }^{101}$ The peer review system in the Convention on Nuclear Safety focuses

95. See Monitoring Symposium Report, supra note 8, at 8-11.

96. Id. at 9 .

97. Id. at 9-10.

98. See OCHR Expert Paper, supra note 12, ฯ ฯ 67-72 ("A peer review mechanism involving systematic examination and assessment of the performance of a State by other States, with the ultimate goal of helping the reviewed State improve its policy making, adopt best practices and comply with established standards and principles may also be a valuable monitoring tool."). Id $\uparrow 67$.

99. Under the IAEA system, a member state makes an official request to the IAEA concerning a particular nuclear facility in the state. Next, a preparatory meeting with the regulatory body and plant management occurs, followed by the recruitment of external experts, usually by the IAEA staff member leading the mission. Finally, technical preparation of the review mission begins. In some cases the plant is expected first to carry out an in-depth self-assessment of its management and operational practices. During the peer evaluation, expert missions conduct on-site evaluations of the nuclear facility and compare the domestic regulatory practices with the pertinent international guidelines. After the mission, the review team submits a final report of its recommendations and findings. See Monica J. Washington, The Practice of Peer Review in the International Nuclear Safety Regime, 72 N.Y.U. L. Rev. 430 (1997).

100. Convention on Nuclear Safety, adopted 17 June 1994, INFCIRC/449 (1994); see generally Menno T. Kamminga, The IAEA Convention on Nuclear Safety, 44 INTL \& Comp. L. Q. 872 (1995).

101. Id. arts. 5, 20. 
on states' behavior vis-à-vis the establishment of regulatory frameworks consistent with their treaty obligations. ${ }^{102}$

While the Convention on Nuclear Safety does not purport to create the kind of specific international standards familiar to other treaty regimes, the system of incentives and accountability created by its peer review model was designed to facilitate the gradual phasing-in of standards promulgated by the IAEA. Thus, its model offers a type of review that is less adversarial than standard compliance-monitoring systems and more cooperative in the sense of providing a means of assisting nuclear operators with the application of commonly accepted international practices.

The American University group further proposed that consideration be given to targeted inspections, thematic inquiries, and fact-finding under which certain thematic issue areas might be identified for external monitoring by fact-finding teams or inspection panels. ${ }^{103}$ Under this model, procedures would be focused; while they would not try to assess compliance across the board, they would set priorities for inspection, thereby making the process more efficient and effective. The primary models cited for this process were those which monitor prison conditions and the prevention of torture. ${ }^{104}$ It was also suggested that external monitoring might take the form of "challenge inspections" whereby a state might self-certify compliance with treaty obligations in a particular area (e.g., prison conditions for detainees with disabilities or conditions in institutions), and others, such as another state party, NGOs, or a treaty body, could challenge the veracity of the report and a neutral entity conduct the inspection. ${ }^{105}$

These approaches are consistent with a core theme regarding the successful implementation of the CRPD upheld by many during the treaty negotiation, namely, that effective implementation would require carrots and sticks. Indeed, many proposals for treaty body reform within the UN human rights system have emphasized that effective implementation rests not only with adversarial processes of engagement, but likewise with more creative and cooperative mechanisms that facilitate implementation through incentives for compliance. ${ }^{106}$

102. Id. arts. 7,8 .

103. See Monitoring Symposium Report, supra note 8, at 8-11.

104. See id. at 10-11.

105. See id. supra note 8 , at 8-11.

106. See, e.g., Effective Functioning of Bodies Established Pursuant to United Nations Human Rights Instrument: Final Report on Enhancing the Long-Term Effectiveness of the United Nations Human Rights Treaty System, U.N. ESCOR, Comm'n on Hum. Rts., 53rd Sess., Agenda Item 15, - 33, U.N. Doc. E/CN.4/1997/74 (1996) available at http:// documents-dds-ny.un.org/doc/UNDOC/GEN/G97/114/45/pdf/G9711445.pdf (proposing, among other things, the establishment of a new state advisory services project that would assist states in conducting pre-ratification surveys and state reporting); Anne Gallagher, Making Human Rights Treaty Obligations a Reality: Working with New Actors and Partners, in FUTURE OF UN, supra note 10, at 201 (proposing proactive engagement of treaty 


\section{Conference of States Parties as a Component of Implementation}

The final text of the CRPD contains a less robust provision providing for a periodic Conference of States Parties than that supported by some adherents. ${ }^{107}$ Some proposals called for a more developed provision, building in a detailed and far-reaching mandate for Conferences of States Parties and drawing on other provisions in international agreements. ${ }^{108}$ Traditionally, Conference of States Parties mechanisms are utilized by states parties to human rights conventions in order to amend or adopt protocols to existing agreements, ${ }^{109}$ rather than as mechanisms for engaging states parties on implementation dialogue. ${ }^{110}$

Significantly, the Mexico proposal also included a provision allowing for a Conference of States Parties that would meet periodically to "[e]valuate the operation and status of the Convention," "[p]romote international cooperation and assistance," "consider recommendations and suggestions

monitoring bodies by NHRIs, including involving NHRIs in the constructive dialogue process and in pre-review of state reports).

107. CRPD, supra note 1, art. 40.

108. Mexico contemplated the establishment of a Conference of States Parties mandated to (i) evaluate the operation and status of the Convention; (ii) promote international cooperation and assistance; (iii) consider the recommendations and suggestions put forward by the Committee; and (iv) elaborate a final report on the agreements reached at the Conference for submission to the Secretary General. See Mexico Proposal, supra note 8, art. 19. The proposal put forward in the legal analysis prepared by Janet Lord and Katherine Guernsey solicited by the Permanent Mission of Mexico to the United Nations endorsed the concept of a Conference of States Parties and sought to endow the Conference with the authority to establish subsidiary bodies to help facilitate implementation. See Commentary of Landmine Survivors Network for the Permanent Mission of Mexico to the United Nations, art. 19, associated commentary (21 May 2003) (on file with the authors).

109. See, e.g., OPCAT, supra note 16; Convention on Conventional Weapons, Amended Protocol V on Explosive Remnants of War, CCW/MSP/2003/3, appendix II (18 Feb. 2004).

110. Human rights conventions have not traditionally utilized Conferences of States Parties to the extent that other international treaties have, and typically they make reference to such meetings only in the context of amending the convention but the CRPD goes further than previous human rights conventions. See, e.g., ICCPR, supra note 16, art. 51(1).

Any State Party to the present Covenant may propose an amendment and file it with the SecretaryGeneral of the United Nations. The Secretary-General of the United Nations shall thereupon communicate any proposed amendments to the States Parties to the present Covenant with a request that they notify him whether they favor a conference of States Parties for the purpose of considering and voting upon the proposals. In the event that at least one third of the States Parties favors such a conference, the Secretary-General shall convene the conference under the auspices of the United Nations. Any amendment adopted by a majority of the States Parties present and voting at the conference shall be submitted to the General Assembly of the United Nations for approval.

ICCPR, supra note 16, art. 51(1). For a discussion of Conferences of States Parties within the context of the CRPD negotiations, see OHCHR Expert Paper, supra note 12, 65-66. 
put forward by the Committee of Experts," and "[e]laborate a final report on the agreements reached at the Conference and submit it to the Secretary General of the United Nations." While the final text provides scope for the Secretariat of Conferences of States Parties to utilize the forum in a way that advances implementation along the lines of the Conference of States Parties to the Mine Ban Treaty ${ }^{111}$ or other international agreements, it remains unclear whether it will be developed in such a direction.

\section{E. Regional Engagement}

The issue of regional-level engagement on disability issues and, in particular, CRPD implementation, was the focus of intense lobbying among some participants. An early monitoring proposal in the Bangkok draft clearly emanated from the successful work in the Asia Pacific region under the Economic and Social Commission for Asia and the Pacific and its Decade on Disabled Persons. ${ }^{112}$ This proposal required the treaty body to meet periodically within the regions under the auspices of existing regional commissions. ${ }^{113}$ Similarly, other proposals reflected the recent practice of the $\mathrm{OHCHR}$ and its regional engagement for treaty body follow-up procedures. ${ }^{114}$ For example, it hosted

111. Pursuant to Articles $11 \& 12$ of the Mine Ban Treaty, periodic meetings of states parties form part of the implementation process. See Mine Ban Treaty, supra note 69. Meetings of states parties were held on an annual basis during the first five years of the life of the treaty, along with intercessional meetings, all of which helped to jump start the implementation process. Thereafter, review conferences were held to continue the implementation process. This could well have been an approach taken with regard to the CRPD, committing to regular meetings of states parties in the initial phase of the Convention's entry into force. For more on Mine Ban Treaty implementation and meetings of states parties, see the International Campaign to Ban Landmines website, available at http://www.icbl.org/treaty/meetings.

112. See United Nations, "Foreword," Focus on Ability, Celebrate Diversity: Highlights of the Asian and Pacific Decade of Disabled Persons, 1993-2002, Social Policy Paper No. 13 (2003), available at http://www.unescap.org/esid/psis/publications/spps/13/foreword. htm.

113. See Bangkok Proposal, supra note 9, pmbl(d). ("Noting with great satisfaction that the Standard Rules on the Equalization of Opportunities for Persons with Disabilities have played an important role in influencing the promotion, formulation, and evaluation of the policies, plans, programs, and actions at the national, regional, and international levels to further the equalization of opportunities by, for and with persons with disabilities.") Id. art. 40(4). ("The meetings of the Committee shall be held at United Nations Headquarters and on a rotational basis at the offices of the regional commissions of the United Nations.")

114. See Office of United Nations High Commissioner for Human Rights, Annual Report 2005: Implementation of Activities AND USE Of Funds 36 (2005), available at http://www.ohchr.org/ Documents/AboutUs/annualreport2005.pdf

A number of activities were carried out to facilitate and enhance implementation of treaty body recommendations at the country level. Three national follow-up workshops were convened in Croatia, Rwanda and Sri Lanka and one global training session for participants from five countries was held in Geneva in May for representatives of NGOs, national human rights institutions 
regional meetings to follow up on various treaty bodies' concluding observations as a means for government actors and civil society to participate in these international processes. ${ }^{115}$ Some cautioned against taking the concept of regional implementation too far, stating that while regional dialogue and information sharing should be encouraged, a monitoring system that leads to regional interpretations of an international convention-and therefore potentially conflicting jurisprudence-may not be desirable. ${ }^{116}$

Still, the opportunity to ensure some level of engagement among states on CRPD implementation at the regional level through explicit language in the text was lost. Also gone was the potential for dialogue that might foster information sharing and knowledge transfer in what will most surely be a busy period of law reform and development in the ratification phase. Given the dearth of appropriate disability law frameworks at the national level, particularly in view of ratification by the European Community, such an opportunity could have been fruitful. Nevertheless, regional cooperation has been growing, with a particularly strong example being the sponsoring of workshops and sharing of technical information and best practices by the Asia Pacific Forum of National Human Rights Institutions. ${ }^{117}$

\section{F. Implementation Facilitation Beyond Traditional Human Rights Monitoring Schemes}

There is merit in exploring how traditional approaches to monitoring by human rights institutions could be usefully expanded to include components seen in other treaty contexts. This is particularly true for the practice of establishing technical advisory bodies, an issue discussed among some participants in the monitoring debates. In this context, proponents pointed to a number of environmental conventions that have established subsidiary

115. Id.

and the media to encourage engagement with the human rights treaty body system. The global session followed national preparatory workshops in the five participating countries: Bosnia and Herzegovina, Mauritius, Thailand, Uganda and Zambia.

A follow-up workshop on the implementation of recommendations of the Committee on the Rights of the Child was held in Buenos Aires, Argentina in November 2005 in cooperation with Plan International and UNICEF. The Branch supported the deployment of human rights officers to $\mathrm{OHCHR}$ regional offices in Santiago and Bangkok, as well as to the newly established field office in Nepal.

116. Indeed the issue of normative consistency has arisen not only vis-à-vis regional human rights systems but also within the human rights treaty monitoring systems itself where there is recognition of the need to maintain consistency among the treaty bodies. UN Initial Report, supra note 10, at 49-51.

117. See The Asia Pacific Forum of National Human Rights Institutions Advisory Council of Jurists, INTERIM REPORT (2006), available at http://www.ahrcentre.org/documents/ACJ\%20maria\%20 graterol.pdf. 
bodies to undertake particular advisory and related roles to facilitate and support implementation. ${ }^{118}$ These bodies perform specialized functions that a treaty monitoring body alone would be unable to undertake.

As an example, the Convention on Biological Diversity ${ }^{119}$ established a Subsidiary Body on Scientific, Technical, and Technological Advice, as well as other subsidiary organs such as an Open Ended Working Group on Biosafety, an Expert Panel on Access and Benefit Sharing, and an Open Ended Ad Hoc Working Group on Article 8(j), which relates to the preservation of practices of indigenous and local communities relevant to biodiversity. ${ }^{120}$ Thus, where particular expertise is required to assess information relating to the implementation of a treaty, technical bodies may serve a useful purpose and can serve a treaty body and states parties by acting in an advisory capacity. Technical committees of this nature typically have data-gathering and specific thematic advisory roles, quite apart from the monitoring responsibilities of the main treaty monitoring committee. Such treaty-established technical bodies are often comprised of individuals with particularized expertise. ${ }^{121} \mathrm{~A}$ technical body appointed by the CRPD Committee could also emulate work in the environmental and arms control areas by suggesting empirical indicators that would facilitate individual and comparative analysis on progress achieved under the Convention.

While the idea to provide an explicit mandate for the Conference of States Parties-or even the Committee- - to establish such technical bodies was not taken up by the drafters, there is nothing within the terms of the CRPD to prohibit this type of innovation. ${ }^{122}$ There are some obvious issue areas that could benefit from such an approach, where a technical advisory body might

118. See, e.g., Monitoring Symposium Report, supra note 8, at 5, 8.

119. Convention on Biological Diversity, adopted 5 June 1992, U.N.T.S. 1993 (entered into force, 29 Dec. 1993), available at http://www.cbd.int/convention/convention.shtml.

120. For more on the institutions established pursuant to the Convention on Biological Diversity, see the official Convention website, Text of the Convention on Biological Diversity, adopted 5 June 1992, 1760 U.N.T.S. 79 (entered into force 29 Dec. 1993) available at http://www.cbd.int/convention/convention.shtml.

121. Thus, for example, a subsidiary body established pursuant to the Convention on the Conservation of Migratory Species of Wild Animals of 1979 (the Bonn Convention), the Scientific Council of the Bonn Convention, provides that its members shall consist of "qualified experts." See Convention on the Conservation of Migratory Species of Wild Animals, (23 June 1979), art. VIII(2), 1990 U.K.T.S. No. 87, available at http://www.cms. int/pdf/convtxt/cms_convtxt_english.pdf.

122. For more on subsidiary bodies, particularly in the context of environmental law agreements where they are common, see Robin R. Churchill \& Geir Ulfstein, Autonomous Institutional Arrangements: A Little-Noticed Phenomenon in International Law, 94 Am. J. INT'L L. 623, 626 (2000). Significantly, Churchill and Ulfstein argue persuasively that the doctrine of implied powers should apply when determining the internal powers of institutions created by way of international agreements. See id. at 633-34. This argument could well be applied to both the CRPD Conference of States Parties and, potentially, the CRPD Committee itself with regard to certain institutional decision-making matters such as the creation of working groups or other subsidiary bodies, among other things. 
be appropriate. A technical body could: develop and facilitate implementation of accessibility standards as under Article 9; further explicate how the general principles of the CRPD of Article 3 should animate approaches to habilitation and rehabilitation under Article 26 and the provision of health care services in Article 25; and, finally, create possible frameworks for implementing the progressive but under-developed model for supported decision-making of Article 12. The CEDAW Committee provides a good practice example in developing innovative relationships with NGOs and other interested groups through non-binding communications that include conferences and working groups for the development of general recommendations.

\section{G. Financial Mechanism Proposals}

Some participants during the CRPD development process emphasized the necessity of appropriate financial support to facilitate implementation. ${ }^{123}$ Their assertions were bolstered by the fact that some eighty percent of persons with disabilities live in poverty in the developing world, ${ }^{124}$ and that the vast majority of states, both developed and developing have little in the way of rights-based disability domestic law and policy frameworks. ${ }^{125}$ Although many of the treaty obligations might be readily implemented without an extensive outlay of resources, the comprehensive nature of the treaty coupled with the undeveloped state of disability laws, policies, and programs will require financial resources. ${ }^{126}$

123. See, e.g., 4th Sess. of the Ad Hoc Comm., 5th Summary, U.N. Convention on the Rights of People with Disabilities (27 Aug. 2004) (intervention by Cuba). In supporting the need for international cooperation and financial support of developing countries, the representative for Cuba identified: "a number of challenges for developing countries seeking to promote the human rights of persons with disabilities, including shortage of resources, poverty, foreign debt, 'imposition of neo-liberal policies,' globalization, and a 'prevailing unjust world order.'" Id. See also 4th Sess. of the Ad Hoc Comm., 6th Summ., U.N. Convention on the Rights of People with Disabilities (30 Aug. 2004), available at http://www.un.org/esa/socdev/enable/rights/ahc4sum30aug.htm. (Intervention by the Coordinator) (expressing his understanding that the language referencing international cooperation involves "recognition that there are some provisions with considerable economic impact and that will require the application of considerable financial resources by States to implement them.")

124. See Second Annual Report on the Implementation of USAID Disability Policy 2 (2000), available at http://pdf.dec.org/pdf_docs/PDABT610.pdf. For a sense of the varying levels of disability reported from country-to-country, see United Nations Department of Economics and Social Affairs, Statistics Division. Demographic and Social Statistics, available at http://unstats.un.org/unsd/demographic/sconcerns/disability.

125. See Stein \& Stein, supra note 72, at 1205 ("[l]t is imperative to identify good legislative practices that can be used as models by States, especially for the majority that lack domestic disability-related measures.")

126. For a review of the underdeveloped state of domestic disability law circa 2002, see Theresia Degener \& Gerard Quinn, A Survey of International, Comparative and Regional Disability Law Reform, in Disability Rights Law and Policy: International and National Perspectives 3, 
It was against this backdrop that the issue of financial support arose in various contexts throughout the negotiations. Much of the debate revolved around the controversial insertion of an article on international cooperation. ${ }^{127}$ Several states took "international cooperation" as code for resource transfers from developed countries to developing countries. ${ }^{128}$ This tension was resolved by the inclusion of a much weakened provision on international cooperation that removed language that would clearly obligate resource transfers. ${ }^{129}$ There were, however, some informal discussions that sought to explore other avenues of financial support for implementation, including the establishment of new financial mechanisms or the engagement of existing ones. ${ }^{130}$ One report reviewed progress made in the international environmental realm, where it is now readily recognized that the development of

25-45 (Mary Lou Breslin \& Sylvia Yee eds., 2002), available at http://www.dredf.org/ international/degener_quinn.html. For a perspective on the need for financial assistance for developing countries, see People with Disability Australia, Intervention by NGO Delegate from Vanuatu, John Suran at the Sixth Session of the Ad Hoc Committee, U.N. Convention on the Rights of People with Disabilities (Aug. 2005).

127. See CRPD Optional Protocol, supra note 2, art 32(1).

States Parties recognize the importance of international cooperation and its promotion, in support of national efforts for the realization of the purpose and objectives of the present Convention, and will undertake appropriate and effective measures in this regard, between and among States and, as appropriate, in partnership with relevant international and regional organizations and civil society, in particular organizations of persons with disabilities. Such measures could include, inter alia: (a) Ensuring that international cooperation, including international development programmes, is inclusive of and accessible to persons with disabilities; (b) Facilitating and supporting capacitybuilding, including through the exchange and sharing of information, experiences, training programmes and best practices; (c) Facilitating cooperation in research and access to scientific and technical knowledge; (d) Providing, as appropriate, technical and economic assistance, including by facilitating access to and sharing of accessible and assistive technologies, and through the transfer of technologies. 2. The provisions of this article are without prejudice to the obligations of each State Party to fulfil its obligations under the present Convention.

128. This undercurrent is well reflected in the debates on Article 32. See, e.g., Disability Treaty Negotiations Daily Summaries (2 \& 3 Feb. 2006), available at http://www.un.org/ esa/socdev/enable/rights/ahc7sum02feb.htm; http://www.un.org/esa/socdev/enable/rights/ ahc7sum03feb.htm.

129. CRPD Optional Protocol, supra note 2, art. 32(2), available at http://www2.ohchr.org/ english/law/disabilities-convention.htm.

The first section of the article is identical in the draft version; however, two distinct versions of section (2) are proposed: [2. States Parties recognize further that while international cooperation plays a supplementary and supportive role, each State Party undertakes to fulfill its obligations under the present Convention.] [2. The provisions of this article are without prejudice to the obligations of each State Party to fulfill its obligations under the present Convention.].

130. A strong undercurrent was the overwhelming consensus that the existing human rights treaty body system was woefully under funded, as emphasized in countless treaty body reform papers. See, e.g., UN Initial Report, supra note 10, ๆ ๆ 54-109 (arguing against voluntary state funding of the treaty body system and amendment of existing human rights treaties to vest funding responsibility in the $U N$, coupled with suspension of rights for non-payment and the pursuit of alternate funding); Elizabeth Evatt, Ensuring Effective Supervisory Procedures: The Need for Resources, in FUTURE OF UN, supra note 10, at 461-65 (proposing, among other things, new sources of support, long range strategy for resource development, and dedicated UN budget for treaty monitoring bodies). 
environmental rules and standards and the provision of financial resources to ensure their implementation all go hand in hand. ${ }^{131}$

Thus, development of a financial mechanism, which might have taken the form of a voluntary fund, was put forward as a way to help foster technical assistance geared toward treaty implementation. ${ }^{132}$ The language in Article 32 ensuring that development programming is made inclusive clearly contemplates appropriate resource allocation, such as building accessible schools and medical clinics, ensuring that persons with disabilities are included in HIV/AIDS and other health programming, and engaging DPOs in election processes, to name just a few obvious examples. Unfortunately, the opportunity of jump-starting implementation particularly in developing countries with seed or pilot funding was missed and it remains the case that some developing countries are wary of ratification (and additional human rights implementation), absent some measure of resource allocation.

\section{THE CRPD CONFERENCE OF STATES PARTIES AND CRPD COMMITTEE AS AGENTS OF UNITED NATIONS REFORM}

Ultimately, the CRPD Committee together with the Conference of States Parties has the ability, within the context of their respective existing authority and mandates, to establish good practices that can inform broader human rights reform efforts within the United Nations. ${ }^{133}$ The discussion that follows brings to the fore some illustrative innovations that may help to ensure effective

131. See Monitoring Symposium Report, supra note 8, at 6, 14. Many funds have been established, most often within the framework of international environmental conventions, to further environmental protection goals, most typically on a voluntary basis. For example, the Global Environmental Facility, established in 1991 by the World Bank, the UN Environmental Programme, and the UN Development Programme, provides funds to help developing countries meet incremental costs of environmental protection measures relating to climate change, biological diversity, international waters, ozone layer depletion and persistent organic pollutants. It also serves as the financial mechanism for four international environmental treaties, and thus helps fund initiatives that assist developing countries in meeting the objectives of the conventions. Monitoring Symposium Report, supra note 8 , at 14 .

132. One inspiration for looking into funding mechanism was the document entitled Possible Options for the Establishment of a Financial Mechanism for the Implementation of the Rotterdam Convention, which was referenced at one of the expert meetings on monitoring and details a number of funding mechanisms within international environmental law. See Monitoring Symposium Report, supra note 8, at 14. The study in question is UNEP/FAO, Possible Options for the Establishment of a Financial Mechanism for the Implementation of the Rotterdam Convention, U.N. Doc. UNEP/FAO/RC/COP.3/13 (18 July 2006) [hereinafter Financial Mechanisms Study] available at http://www.ciel.org/ Publications/Rotterdam_FinMechStudyll_Secretariat.pdf.

133. See generally Rosemary Kayess \& Phillip French, Out of Darkness into Light? Introducing the Convention on the Rights of Persons with Disabilities, 8 Hum. Rts. L. Rev. 1 (2008). 
CRPD monitoring and implementation. At the same time, it is hoped this discourse will pave the way for enhanced human rights treaty monitoring and implementation more generally.

\section{A. Invigorating the Conference of States Parties}

Increasingly in international law domains, treaties provide for periodic Conference of States Parties for the purpose of assessing strengths and weakness in implementation, sharing information and data, and facilitating coordination and dialogue among all stakeholders, including NGOs. ${ }^{134}$ Depending on how states parties choose to make Article 40 of the CRPD operational, the Conference of States Parties could well serve a function similar to established practice in the arms control and particularly international environmental law processes by achieving consensus on substantive issues. ${ }^{135}$ The Department for Economic and Social Affairs (DESA), as the co-Secretariat for the Convention, is tasked with servicing the Conferences of States Parties. Thus, the extent that Conferences of States Parties can promote policies and practices will rely heavily on the efficacy of DESA's management of those meetings. The OHCHR referred to the Mine Ban Treaty Meetings of states parties "as a forum to discuss issues, such as critical legal definitions, as well as develop further norms and quantitative goals and targets."136 Because of this success, the OHCHR chose to highlight this institutional structure for consideration by CRPD drafters as a "global policy making mechanism."137

Moreover, the Conference of States Parties could draw upon lessons in the environmental realm and use its convening power to stimulate resource allocation to implementation. Significantly, the autonomous institutional arrangements found in international environmental agreements-including conferences or meetings of states parties as well as subsidiary bodies-have played important roles in helping to develop the normative content of the regimes established under the treaty. They likewise have helped facilitate implementation, often through cooperative and facilitative mechanisms, as opposed to adversarial methods. ${ }^{138}$ Such a dynamic might help avoid conflicts that might otherwise arise, for example, from differing views between developed and developing states as to the extent of resource allocation.

A salient, albeit modest, example from which to draw is the Quick Start Programme initiated by the International Conference on Chemicals Man-

134. See, e.g., Mine Ban Treaty, supra note 69, art. 11.

135. See infra Part IV, Section J(1), "Central Clearing House/Unifier of Data Collection."

136. OHCHR Expert Paper, supra note 12, I 65.

137. Id

138. See Churchill \& Ulfstein, supra note 122, at $623,645$. 
agement to implement the Strategic Approach to International Chemicals Management (SAICM). ${ }^{139}$ Quick Start was intended to provide seed money in support of initial capacity-building and implementation activities in developing countries and, while it is time-limited and its funds are modest, there is scope for developing countries to access assistance that can further implementation of their chemical management obligations. ${ }^{140}$ Moreover, the SAICM encourages developing countries to integrate SAICM objectives into their requests for development assistance and indicates that technical support to help them do this will be provided if needed. ${ }^{141}$ Absent politics, there is nothing precluding the Conference of States Parties from establishing a similar initiative with the CRPD.

\section{B. Introducing a Regional Dimension to CRPD Monitoring and Implementation}

While in the end drafters implicitly accepted the argument that the global scrutiny offered by an international treaty body was preferable to regional monitoring, it may benefit the new CRPD Committee and the OHCHR in its Secretariat role to support regional engagement of the type now practiced in relation to the implementation of Convention on the Rights of the Child, which liaises with UNICEF and other entities to achieve progress on the ground. ${ }^{142}$ The Bangkok CRPD draft proposal implicitly acknowledges the potential role that the regions could play in implementation, through a procedure whereby the treaty body would meet periodically within the regions, under the auspices or umbrella of existing regional commissions. ${ }^{143}$ One currently discussed proposal is a Disability Rights Tribunal for Asia and Pacific that would provide regional data, as well as interpretive guidance on cultural implications of the CRPD. ${ }^{144}$

139. For a brief overview, see Financial Mechanisms Study, supra note 132, 1110.

140. See id.

141. See id.

142. See, e.g., LSN Ideas Memorandum on Implementation in Relation to the Convention on the Rights of Persons with Disabilities (July 2004) (on file with authors).

143. See Bangkok Proposal, supra note 9, art. 40(4) ("The meetings of the Committee shall be held at United Nations Headquarters and on a rotational basis at the offices of the regional commissions of the United Nations.")

144. Notable in this respect would be the role of family in facilitated decision making. The effort is sponsored by the Nippon Foundation, and one of the authors is consulting on the development of this body. 


\section{Treaty Committee Experts}

The review of existing treaty bodies within the United Nations human rights system reveals differential levels of expertise and independence among Committee members. Moreover, some members' heavy workloads outside of their Committee responsibilities result in disparate degrees of productivity. In addition, the existing treaty bodies disclose an inadequate representational diversity, leading some proponents of treaty body reform to advocate in favor of a "global search process" overseen by the OHCHR to help establish diversity criteria and help identify suitable candidates. ${ }^{145}$

The drafters of the CRPD did not take suggestions for an enhanced vetting process nor the idea put forward by the $\mathrm{OHCHR}$ for the inclusion of a review procedure within the states parties nomination process to ensure sufficient expertise and qualifications. ${ }^{146}$ It is hoped that such a process could yet be developed, perhaps pursuant to a decision of a Conference of States Parties. ${ }^{147}$ It is likewise hoped that the Committee will be comprised principally of experts with disabilities, all of whom have relevant experience and expertise in human rights and disability law and policy.

\section{NGO Participation in CRPD Monitoring and Implementation}

Drafters clearly contemplated an active role for NGOs in the work of the Committee, which is consonant with the role that NGOs-and DPOs in particular-played in the drafting of the CRPD. Article 38 authorizes the Committee to invite "other competent bodies as it may consider appropriate to provide expert advice on the implementation of the Convention in areas falling within the scope of their activities." 148 This mandate, inter alia, enables the Committee to receive and consider information and advice submitted by civil society organizations in various formats, including written submissions (such as shadow reports) and oral interventions. ${ }^{149}$ Experience has

145. Craig Scott, Bodies of Knowledge: A Diversity Promotion Role for the UN High Commissioner for Human Rights, in Future of UN, supra note 10, at 403, 423.

146. See OHCHR Expert Paper, supra note 12, ๆ 19.

147. See id. Likewise, the language in CRPD does not reflect the very specific articulation of necessary qualifications provided in the OPCAT. See OPCAT, supra note 16, art. 5(4) (referencing the need for "proven professional experience in the administration of justice, in particular criminal law, police or prison administration, or in the various fields relevant to the treatment of persons deprived of their liberty").

148. Supra note 16, art. 38(a).

149. As the OHCHR points out in its Expert Paper prepared for the drafters of the CRPD, the CRC Committee has a particularly well-developed practice of encouraging the receipt of NGO materials and otherwise facilitating active and highly constructive engagement by NGOs in its work. OHCHR Expert Paper, supra note 12, at 27. 
demonstrated that NGO participation is paramount in ensuring that treaty bodies receive useful and credible information as a means of facilitating human rights implementation. ${ }^{150}$ Trenchantly, communications on behalf of aggrieved individuals (including collective/systemic ones) may be submitted to the Committee. Individuals may also directly submit their complaints. This reporting system increases the prospect of civil society's participation in rights monitoring. ${ }^{151}$

\section{E. International Cooperation}

Article 32 of the CRPD makes it clear that all international cooperation efforts, including international development programs, should be accessible and fully inclusive of persons with disabilities. ${ }^{152}$ Specifically, all states parties are required to completely integrate persons with disabilities in all aspects of their aid programs - from design through implementation and evaluation. As characterized by one leading commentator, "States Parties have a duty to proof their development aid programmes from the perspective of the rights contained in the Convention." ${ }^{153}$ The Committee can make this essential requirement operational by questioning states on the measures they have undertaken to ensure that international development programs (whether donor or recipient) are inclusive of persons with disabilities. While the Convention provides no specific guidance on the extent to which it corresponds to the principles and values of other international instruments and processes of development or for making this requirement operational, the Conference of States Parties would be an ideal vehicle for following up on this requirement, as well as a forum for sharing best practices in inclusive development in various sectors. ${ }^{154}$

150. The Expert Paper prepared by the OHCHR to assist the drafters of the CRPD in developing text on monitoring stated: "[a]s an overarching principle, such a monitoring mechanism must provide full participation for persons with disabilities, both in terms of access and participation in the monitoring process, including with respect to meeting venues, documentation and interpretation." Id. ๆ 10.

151. Cf. ICCPR Optional Protocol, supra note 16, art. 1. It should be noted in this respect that the Human Right Committee, in its Rules of Procedure, nonetheless adopted the practice of hearing communications on behalf of alleged victims. The CRPD, however, follows CERD and the Optional Protocol to CEDAW in conferring standing beyond individual complainants. See CERD, supra note 16, art. 14(1); Optional Protocol to the Convention on the Elimination of All Forms of Discrimination Against Women, adopted 6 Oct. 1999, G.A. Res.54/4, U.N. GAOR, 54th Sess., art. 2, U.N. Doc. A/RES/54/4 (1999). 2131 U.N.T.S. 83 (entered into force 22 Dec. 2000).

152. CRPD Optional Protocol, supra note 2, art. 32.

153. Quinn, Resisting the 'Temptation of Elegance', supra note 13, at 254.

154. This has proved a useful practice of the Mine Ban Treaty implementation process in which regular meetings of states parties have provided an important forum for the reporting on and sharing of best practices in Mine Ban Treaty implementation, including, for example, 


\section{F. Forging Linkages with Other Bodies}

The work of the United Nations system on the advancement of the rights of persons with disabilities extends well beyond the CRPD and its attendant monitoring mechanisms. Disability is a cross-cutting issue that should be part and parcel of the work of all United Nations programs. Moreover, there are a number of international, as well as regional, intergovernmental bodies that have some form of responsibility in the issue areas covered by the CRPD, several of which have monitoring responsibilities relating to disability rights. ${ }^{155}$ While the CRPD does contain a provision in Article 38 regarding the relationships of the Committee to other bodies, the type of detailed guidance envisaged by the $\mathrm{OHCHR}{ }^{156}$ was not included. In choosing to chart out its relationship with other UN bodies and mechanisms, the Committee could help achieve the broad vision of the CRPD toward greater inclusion of the human rights of persons with disabilities in law, policy and programming.

Likewise, the Committee can break new ground in realizing the promise of engagement with NHRIs whose contemplated role in national level monitoring can and should be reinforced through the Committee's efforts. This is so especially in view of the important progress already being done within the International Coordinating Committee of NHRIs around CRPD implementation. ${ }^{157}$ The Committee could draw from the experience of the CRC Committee and articulate guidelines for the participation of partners in its work in a proactive effort to promote engagement that is meaningful and substantive. ${ }^{158}$

\section{G. Proactive Inquiries}

CRPD's Optional Protocol includes a procedure of inquiry ${ }^{159}$ similar to that of some human rights monitoring systems, which allows human

expenditures on victim assistance programming and the like. For more on Mine Ban Treaty implementation and meetings of states parties, see the International Campaign to Ban Landmines website, available at http://www.icbl.org/index.php/icbl/Treaties/MBT/ ISC and http://www.icbl.org/index.php/icbl/Treaties/MBT/Annual-Meetings.

155. Thus, for example, the U.N. Mine Action Service has, as one of its pillars, victim assistance. See Susan Fiederlein, Victim Assistance: A Way Forward Emerges, Journal of Mine Action (Dec. 2002), available at http://maic.jmu.edu/Journal/6.3/focus/fiederlein/ fiederlein.htm (discussing victim assistance as a pillar of UNMAS programming).

156. See OHCHR Expert Paper, supra note 12, ๆ 64.

157. For more on this work, see Harvard Law School Project on Disability, available at http:// www.hpod.org.

158. See CRC Guidelines for the Participation of Partners (NGOs and Independent Experts) in the Pre-Sessional Working Group of the Comm. on the Rts. of the Child, U.N. GAOR, Comm. on the Rts. of the Child, 22d Sess., at 111, U.N. Doc. CRC/C/90 (1999), available at http://www2.ohchr.org/english/bodies/crc/docs/guidelines-E.pdf.

159. See CRPD Optional Protocol, supra note 2, art. 6. 
rights monitoring systems to initiate investigations regarding egregious or systematic human rights violations. ${ }^{160}$ In such cases, the Committee shall call on that state party to collaborate in an investigation and submit its observations ${ }^{161}$ for review. ${ }^{162}$ The CRPD includes in its Optional Protocol a procedure of inquiry, ${ }^{163}$ employed within some human rights monitoring systems, to allow human rights monitoring systems to initiate investigations, particularly regarding egregious or systematic human rights violations. ${ }^{164} \mathrm{~A}$ procedure of inquiry is triggered in cases where the Committee receives "reliable" information relating to "grave or systematic violations by a State Party of rights set forth in the Convention."165 One might well imagine, for example, an inquiry concerning the institutionalization of persons with disabilities or the systematic exclusion of disabled children from schools. In such cases, the Committee shall call on that state party to collaborate in an investigation of the situation and submit its observations. ${ }^{166}$ Thereafter, the Committee reviews the information submitted by the state party and other reliable information submitted by other parties. ${ }^{167}$

The Committee may choose to authorize one or more of its members to conduct an inquiry and report "urgently" to the Committee. ${ }^{168}$ Such an inquiry may include a visit to the territory of the state party subject to consent of the state party (consent being a standard principle of international legal process). The findings of any such inquiry are sent to the state party, along with Committee "comments and recommendations." 169 The state party is given an opportunity to respond within six months. ${ }^{170}$ The procedure is confidential; accordingly, the proceedings are entirely closed and the written findings are not made public. ${ }^{171}$ The Committee may solicit the state party after six months to appraise it of what measures it assumed in reply to the inquiry, ${ }^{172}$ and may invite the state party to include details of these measures in its habitual CRPD report. ${ }^{173}$

160. See, e.g., CAT, supra note 16, art. 20.

161. See CRPD Optional Protocol, supra note 2, art. 6(1).

162. See id. art. 6(2).

163. Id. art. 6 .

164. See, e.g., CAT, supra note 16, art. 20; see also the Charter-based 103 communications procedure, now administered under the Human Rights Council pursuant to U.N. Human Rights Council: Institution Building, U.N. Doc. A/HRC/5/L.2/Annex (18 June 2007) available at http://www.ohchr.org/english/bodies/chr/complaints.htm.

165. CAT, supra note 16 , art. 6 .

166. Id. art. 6(1).

167. Id. art. 6(2).

168. Id.

169. Id. art. 6(3).

170. Id. art. 6(4).

171. Id. art. 6(5).

172. Id. art. $7(2)$.

173. Id. art. 7(1); CRPD, supra note 1, art. 35. 
Such follow-up procedures in relation to communications or inquiry mechanisms enhance compliance with recommendations and other measures. Whether the Committee will proactively engage in such follow-up will depend upon the resources at its disposal, as well as the manner in which it perceives its mandate. It must be underscored, however, that the efficacy of any procedural innovations related to reporting will be determined by the extent that the Committee follows up on these measures. For example, the Committee could assign one or more members specifically to follow up with states; the elicited information would then be made publically available for use by civil society and other monitoring agents.

\section{H. CRPD Secretariat, Department of Economic \& Social Affairs, and the UN Special Rapporteur on Disability}

DESA is and will continue to be responsible for the oversight of the implementation of the World Programme of Action Concerning Disabled Persons ${ }^{174}$ and the UN Standard Rules, ${ }^{175}$ as well as other disability-related standards and guidelines through its CRPD Secretariat. DESA will also serve as the Secretariat for the Conference of States Parties pursuant to Article 40 of the Convention. ${ }^{176}$ Additionally, DESA services the Special Rapporteur on Disability, which was established by and reports to the Commission on Social Development, outside the framework of the UN human rights system. The Office of Special Rapporteur position is separate from the special rapporteurs and other special procedures falling under the Human Rights Council and serviced by the OHCHR. ${ }^{177}$ It will be essential for DESA to facilitate the engagement of the Special Rapporteur in the work of the Committee on Disability and indeed other human rights mechanisms. Likewise, DESA must

174. World Programme of Action Concerning Disabled Persons, adopted 3 Dec. 1982, G.A. Res. 37/52, U.N. GAOR Supp. No. 51, 37th Sess., U.N. Doc. A/37/51 (1982), available at http://www.icrpd.net/implementation/en/toolkit/files/World\%20Programme $\% 20$ of $\% 20$ Action.htm.

175. See The Standard Rules on the Equalization of Opportunities for Persons with Disabilities, adopted 20 Dec. 1993, 85th Plenary Meeting, I 1, Part IV, A/Res/48/96, available at http://www.un.org/esa/socdev/enable/dissre00.htm.

176. See CRPD, supra note 1 , art. 40(1).

177. The Special Rapporteur on Disability is endowed with responsibility to consult with a panel of experts established pursuant to the UN Standard Rules and present states with questions concerning their implementation of the Standard Rules. There are a number of disadvantages in having the Special Rapporteur on Disability fall outside the Human Rights Council's purview, including non-participation in the coordinating structure of the special procedures and the limited opportunities to draw from the experience of the other special procedures to facilitate their work on disability issues. For more on the special procedures (such as special rapporteurs and thematic mechanisms), see the OHCHR website at http://www.ohchr.org/EN/HRbodies/Pages/HumanRightsBodies. aspx. 
be proactive in ensuring that the Conference of States Parties is a meaningful forum within which to promote communication and interaction between the Special Rapporteur, the Committee, and other parties, including states, UN agencies, NHRIs and NGOs.

It is not clear whether the appointment of the Special Rapporteur on Disability will continue to be renewed indefinitely now that the CRPD is in place and operational. Nonetheless, assuming the future existence of the office and drawing from the experience of special rapporteurs created within the framework of the United Nations human rights system and serviced by the OHCHR, there are ways in which the Special Rapporteur on Disability could relate to the new convention implementation structure (and the United Nations human rights system more generally) and use the office to ensure that existing instruments on disability are understood and operationalized consistent with the CRPD. ${ }^{178}$ It should be noted, however, that proposals to make the Special Rapporteur on Disability an ex officio member of the Committee received little support during the course of the negotiations and no specific reference was made to the Special Rapporteur in the final convention text. ${ }^{179}$ Although this may not be a bad omission, issues relating to overlap and coordination—not to mention the continued existence of the Special Rapporteur on Disability and the role of the Human Rights Committee in appointment of such individuals - must be addressed in future. The proposal by the OHCHR for a provision providing detailed guidance on the relationship between the different mechanisms, such as the thematic procedures, ${ }^{180}$ was not taken up. Likewise, the proposal by the OHCHR for a specific provision to address the relationship between the Committee and the Special Rapporteur on Disability went unaddressed. ${ }^{181}$ However, the Committee, working together with the OHCHR and DESA, could address this gap.

\section{General Principles and the Animation of Monitoring and Implementation}

The CRPD stands out among core international human rights conventions in its articulation of general principles, which are set forth in a separate article. ${ }^{182}$ Although the explicit articulation of general principles is a common

178. Cf. Aaron A. Dhir, Human Rights Treaty Drafting Through the Lens of Mental Disability: The Proposed International Convention on Protection and Promotion of the Rights and Dignity of Persons with Disabilities, 41 Stan. J. INT'L. L. 181 (2005) (discussing the prospects of having a disability Ombudsman).

179. See Compilation of Proposals, supra note 74, art. 28(5).

180. See OHCHR Expert Paper, supra note 12, ฯ 64.

181. Id. I 24.

182. CRPD, supra note 1 , art. 3 . 
feature of international environmental agreements ${ }^{183}$ and other framework conventions, ${ }^{184}$ human rights conventions have not contained specific provisions outlining general principles. At best, treaty bodies have identified such principles, as in the case of the CRC. ${ }^{185}$ The Committee will need to explicate the application of the general principles across the treaty text for states parties, including in the realm of monitoring and implementation. This may be accomplished not only through the review of states parties reports, but likewise in the formulation of general comments on the treaty text. ${ }^{186}$

Thus, in keeping with the suggestions put forward in the context of drafting the CRPD monitoring mechanism, the Committee will need to ensure that, "[a]s an overarching principle ... [the] monitoring mechanism must provide full participation for persons with disabilities, both in terms of access and participation in the monitoring process, including with respect to meeting venues, documentation and interpretation."1187 The initial meeting of the Committee on Disability suggests that states parties are indeed looking for guidance on the interpretation of the text and other types of assistance related to the explication of their obligations. ${ }^{188}$ Ultimately, the efficacy of these proposals will depend on the Experts themselves, and the extent to which they commit to proactive roles.

\section{J. Process and Working Methods}

In relation to its process and working methods, the Committee may wish to emulate best practices from existing treaty bodies, as well as incorporate suggested reforms. ${ }^{189}$ For example, one commentator has advocated increas-

183. See, e.g., United Nations Framework Convention on Climate Change, adopted 9 May 1992, (entered into force 24 Mar. 1994), reprinted in 31 I.L.M. 849 (1992), art. 4(1)(i), available at http://unfccc.int/resource/docs/convkp/conveng.pdf.

184. See, e.g., WHO Framework Convention on Tobacco Control, available at http://whqlibdoc.who.int/publications/2003/9241591013.pdf.

185. The Committee on the Rights of the Child has opined that states are obliged to implement CRC obligations within the context of its basic principles which include the principle of non-discrimination, best interests of the child, the right to life, maximum survival and development, and participation. General Measures of Implementation of the Convention on the Rights of the Child, General Comment No. 5 9 12, U.N. GAOR, Comm. on Rts. of the Child, 34 $4^{\text {th }}$ Sess., U.N. Doc. CRC/GC/2003/5 (2003), available at http:// www.unhchr.ch/tbs/doc.nsf/898586b1dc7b4043c1256a450044f331/3bba808e47bf25a 8c1256db400308b9e/\$FILE/G0345514.doc.

186. The general comments of the human rights treaty bodies and other work product may be accessed through the OHCHR website, as well as the Netherlands Institute of Human Rights web page, available at http://sim.law.uu.nl/sim/Dochome.nsf.

187. OHCHR Expert Paper, supra note 12, ๆ 10.

188. For a review of these initial discussions of the Committee on Disability, see CRPD, 1st Sess. Ad Hoc Comm.(2009), available at http://www.ohchr.org/EN/HRBodies/CRPD/ Pages/Session1.aspx.

189. The OHCHR Expert Paper is perhaps the most detailed work disclosing how specific processes and working methods could best be adopted for the new CRPD Committee 
ing the efficiency of the International Convention on the Elimination of All Forms of Racial Discrimination body by adopting procedural rules that allow the Chair to solely congratulate states representatives for their participation, mandate convening sessions on time, ${ }^{190}$ delegate work in advance of formal sessions, and limit non-pertinent interventions by members. ${ }^{191}$ Such proposals, formulated in the context of treaty body practice, should make their way into the development of the Committee working methods as appropriate. These ostensibly mundane matters assume significance when one considers the daunting time constraints of human rights treaty bodies. The following five sub-sections set forth procedural powers of the Committee and flexible adaptations of working methods to advance CRPD implementation.

\section{Working Methods to Focus on Thematic Issues}

Other potential measures for enhancing the Committee's productivity through procedural rules might include authorizing the creation of subsidiary bodies such as working, thematic, and technical advisory sub-groups. Within the context of the Committee's work, it might be useful to commission subgroups on specialized issues such as legal capacity or election access for persons with disabilities and to have these entities supported in their tasks by bodies authorized under the CRPD. ${ }^{192}$ These working methods may be particularly important given the traditional dearth of meeting time allocated for these bodies to conduct their work.

in the light of lessons learned and current treaty body practice. See generally OHCHR Expert Paper, supra note 12.

190. Karl Josef Partsch, The Committee on the Elimination of Racial Discrimination, in UNITED Nations and Human Rights 339, 365-66 (Philip Alston ed., 1992).

191. Id. at 366 .

192. CRPD, supra note 1 , art. 38. The tasking of technical bodies with advisory responsibilities is a common and helpful practice within other international treaty domains. International environmental agreements routinely establish standing committees or scientific councils mandated to provide recommendations on technical matters, necessary research, coordination of research, evaluation of results, and other specialized matters bearing upon the implementation of the treaty. See, e.g., United Nations Framework Convention on Climate Change, adopted 9 May 1992, art. 9, (entered into force 24 Mar. 1994), reprinted in 31 I.L.M. 849 (1992), available at http://unfccc.int/not_assigned/b/ items/1417.php; Convention on the Conservation of Antarctic Marine Living Resources, adopted 20 May 1980, art. XV, (entered into force 7 Apr. 1982), reprinted in 19 I.L.M. 849 (1980), available at http://www.ccam/r.org/pu/E/quick_links.htm; Convention on the Conservation of European Wildlife and Natural Habitats, adopted 19 Sept. 1979, art. 14, (entered into force 1 June 1982), reprinted in U.K.T.S. 56 (1982), available at http:// conventions.coe.int/Treaty/en/Treaties/Html/104.htm; Convention on the Conservation of Migratory Species of Wild Animals, adopted 23 June 1979, art.VIII, (entered into force 1 Nov. 1983), reprinted in 19 I.L.M. 15 (1980), available at http://www.cms.int/ pdf/convtxt/cms_convtxt_english.pdf. 


\section{Reporting Guidelines/Targeted Lists of Questions for Consideration}

The role of the Committee in articulating reporting guidelines is a particularly important one and the Committee should take up the challenge to follow the best practices of existing treaty bodies in formulating its guidelines. ${ }^{193}$ For example, the Committee on the Rights of the Child has specified reporting guidelines that are well-tailored to the specific obligations set forth in the CRC. ${ }^{194}$ While the drafters did not take up the suggestion of the OHCHR to write into the text the authorization of the Committee to create lists of questions or issues specifically for a state party in the context of its reporting obligation, ${ }^{195}$ the Committee has ample discretion to do so. Thus, for example, where a state is due for reporting and has specific widespread practices ostensibly at odds with the CRPD, such as congregate institutionalization or far-reaching guardianship laws stripping persons with disabilities of legal capacity, these issues could be brought to the attention of the reporting state party who could then come prepared to address these matters in substantive detail.

\section{Late Reporting}

In the event a report is "significantly overdue," the Committee may give the state party in question a three-month notice to submit a report in conjunction with its CRPD implementation. ${ }^{196}$ This past due provision is a novel advance but does reflect an established, albeit relatively rare, practice among treaty monitoring bodies to review implementation in the absence of a report. This provision has the potential to facilitate and expedite state reporting accountability. ${ }^{197}$ It is thus within the discretion of the Committee to take a more proactive role in addressing delinquency in reporting by states parties. In such cases, the Committee could invite NHRIs and NGOs to help fill in the reporting gap and provide these actors with the ability to appear before the Committee and participate in a dialogue regarding country conditions in the relevant non-reporting state. Taking this measure could create an incentive for state compliance in the absence of other enforcement mechanisms.

193. Guidelines on reporting "are designed to ensure that reports are presented in a uniform manner so that [the treaty body] can obtain a complete picture of the situation of implementation." OHCHR Expert Paper, supra note 12, 9 33. For a thorough account of reporting under existing bodies and suggestions directly pertaining to the formulation of reporting procedures under the CRPD, see OHCHR Expert Paper, supra note 12, ๆ 9 22-42.

194. See General Guidelines Regarding the Form and Contents of Periodic Reports To Be Submitted by States Parties, adopted 20 Nov. 1996, Comm. on Rts. of the Child, U.N. GAOR, 13th Sess., 343d mtg., U.N. Doc. CRC/C/58 (1996)), available at http://www. unhchr.ch/tbs/doc.nsf/(Symbol)/CRC.C.58.En?Opendocument.

195. See OHCHR Expert Paper, supra note 12, ๆ 38.

196. See CRPD, supra note 1, art. 36(2).

197. For discussion of this practice, see OHCHR Expert Paper, supra note 12, ๆ 35. 


\section{Communications}

The Committee may, at any time after receiving a communication, but before determining its merits, request that a state party adopt sufficient interim measures "to avoid possible irreparable damage" to the alleged victims of its actions. ${ }^{198}$ However, such action does not imply the ultimate admissibility or merits of the given communication. ${ }^{199}$ The possibility of such precautionary measures is important and has been clearly demonstrated in a petition concerning the rights of persons with mental disabilities before the Inter-American Commission on Human Rights of the Organization of American States. ${ }^{200}$ That case also illustrated the proactive role that can be played by certain monitoring bodies, with the Commission converting an original individual complaint to one that encompassed all individuals institutionalized in the state facility. ${ }^{201}$

Given that the Committee is authorized to hear group complaints ${ }^{202}$ (as well as to make inquiries regarding systemic CRPD violations), ${ }^{203}$ it would follow that similar action would fall within its purview. ${ }^{204}$ In addition, although the Ad Hoc Committee did not take up the suggestion of the $\mathrm{OHCHR}$ for a specific provision allowing the Committee to address urgent situations through early warning measures, it would be within the mandate of the Committee to do so. ${ }^{205}$

198. See CRPD, supra note 1 , art. 4(1).

199. See id. art. 4(2).

200. In December 2003, in a landmark decision on a petition, the Inter-American Commission on Human Rights approved a petition for precautionary measures to protect the lives and physical integrity of people detained in a psychiatric institution in Paraguay and requested that the Government of Paraguay adopt all necessary measures to protect the lives, health, and the physical, mental and moral integrity of the 460 people detained in the institution, with special attention to the situation of women and children. See Precautionary Measures Granted or Extended by the Commission During 2003: Paraguay, on Behalf of the Patients of the Hospital Neurosiquiátrico (Neuro-psychiatric Hospital), in Annual Report of the Inter-American Commission on Human Rights 2003, OEA/Ser./L/V/ II.118, doc. 25., rev. 2 (2001), ch. III.C, I 60. For more on this petition, see the timeline and discussion of this petition on the Mental Disability Rights International website, available at http://www.mdri.org/projects/americas/paraguay/index.htm.

201. Id.

202. CRPD Optional Protocol, supra note 2, art. 1(1).

203. Id. art. 6(1).

204. For example, in International Association Autism - Europe (IAAE) v. France, No. 13/2002, 3.CoE.12 (10 Mar. 2004), the European Committee on Social Rights engaged in a farreaching investigation of the extent to which children with autism were mainstreamed into France's school system.

205. See, e.g., OHCHR Expert Paper, supra note 12, 9 55. CERD developed early warning and urgent action measures in 1993, which may be invoked by the Committee or interested parties. See Working Paper on Prevention of Racial Discrimination, Including Early Warning and Urgent Procedures, Comm. on the Elimination of Racial Discrimination, A/48/18, annex III, available at http://www.ohchr.org/english/bodies/cerd/ docs/A_48_18_Annex_III_English.pdf. 


\section{Central Clearing House/Unifier of Data Collection}

Article 31 of the CRPD requires states parties to "collect appropriate information, including statistical and research data" in order to create and implement policies that give effect to the Convention. ${ }^{206}$ The Article also outlines the standards to be used for the collection, maintenance and use of this information. ${ }^{207}$ The drafters of the Convention were particularly concerned about the dearth of disability-specific statistics and data. ${ }^{208}$ At the same time, the Ad Hoc Committee sought to balance the need to stimulate better practices in this context with the need to ensure that the process by which such data is collected and ultimately used, does not violate the rights of persons with disabilities. ${ }^{209}$ The resulting text reflects these interests and the equilibrium desired. The task of the Committee will be to ensure, within the framework of the reporting process, that disability statistics data are collected and applied in keeping with Article 31. In this regard the Committee might take direction from the CRC Committee which references, in the context of its reporting guidelines, the need for statistical information as a means of effective implementation and monitoring. ${ }^{210}$

Significantly, there is nothing to preclude the Conference of States Parties from taking on the role that many such institutional mechanisms play within the context of environmental or arms control treaties, insofar as they provide opportunities for setting benchmarks and quantitative goals and targets. In this sense, Conferences of States Parties could be utilized as a forum for information exchange based on data and dialogue on progressive tools to aid implementation, including, for example, disability rights budget analysis. Indeed, in order for the data and statistical vision of the CRPD to

206. CRPD, supra note 1, art. 31(1). This provision appears to have its origins in the Bangkok Proposal, supra note 9, art. 33.

207. CRPD, supra note 1, art. 31(1).

The process of collecting and maintaining this information shall: (a) Comply with legally established safeguards, including legislation on data protection, to ensure confidentiality and respect for the privacy of persons with disabilities; (b) Comply with internationally accepted norms to protect human rights and fundamental freedoms and ethical principles in the collection and use of statistics..

208. See, e.g., Working Group Draft, supra note 13, n.23 (noting that the inclusion of an article on data and statistics was regarded as important as it "could allow States to respond more effectively to the needs of persons with disabilities and to have an accurate assessment of the situation of the persons concerned so as to implement programs for their benefit").

209. Id. art. 6 . The initial Working Group text reflects this tension insofar as it focuses heavily, to the point of repetition, on issues of privacy, confidentiality and the like in relation to disability data collection and use. See also the commentary on Article 6 referencing "repetition and redundancies." Janet E. Lord, Katherine N. Guernsey \& Kirsten Young, LSN Legal Commentary on the Draft Convention Text produced by the Working Group to the Ad Hoc Committee (Mar. 2004) (on file with authors).

210. See Committee on the Rights of the Child, Reporting Guidelines to States Parties, supra note 194 , व 7. 
be realized, it is clear that the national research and statistical capacities must be strengthened and further developed for the development, testing and use of Article 31 disability data collection instruments.

\section{CONCLUSION}

The Committee on the Rights of Persons with Disabilities along with the CRPD Conference of States Parties has commenced operations at a time when the United Nations human rights treaty monitoring system is experiencing strong pressure for reform. The established human rights monitoring committees are beset by backlogs in the reporting process and face severe resource challenges that impact their ability to undertake the depth of analysis and engagement with states parties contemplated by their mandates. The CRPD's drafters were well aware of the challenges facing the treaty body system that will likewise face this newest committee. Accordingly, the drafters attempted to account for challenges by incorporating innovations in the resulting monitoring provisions.

Yet, for reasons of political expediency coupled with time constraints that prevented a more considered negotiation process for the monitoring and implementation provisions, those drafters declined to adopt other far reaching mechanisms that could have addressed additional systemic flaws. Secretariat responsibilities are to be shared between Geneva and New York. Technical expertise on human rights and disability issues have been strengthened in both the OHCHR as well as DESA with the hiring of additional staff and engagement with DPOs and academic institutes committed to working on human rights and disability. Experience indicates that a progressive treaty body can make much of even minimalist monitoring and implementation provisions, and given the relatively broader scope offered by the mechanisms in the CRPD, a proactive Committee coupled with the enlightened support of the dual Secretariat structure can be expected to make significant progress towards the realization of the Convention's visionary framework. Moreover, the experience of international environmental law, particularly its pattern of developing creative institutional arrangements such as conferences or meetings of the parties and subsidiary bodies to facilitate cooperative implementation and develop the normative content of a treaty over time, provides ample lessons for the CRPD regime.

The CRPD text itself acknowledges the prospect of human rights treaty body reform, as reflected in Article 47. The prospect of a unified treaty body carries with it particular dangers for CRPD implementation. The Convention was negotiated in large part on the basis that the current system had utterly failed to address disability rights in any on-going, consistent, and competent manner. There is an undeniable tension between calls to adopt a compre- 
hensive and more holistic approach to treaty monitoring and the interest in developing expertise and specialization vis-à-vis specific human rights issue areas and the protection of groups subjected to egregious discrimination, including persons with disabilities as well as other marginalized groups. Any proposal that seeks to develop a unified body needs to address this tension clearly. Moreover, there would need to be some mechanism, even within a unified body, of addressing the specific barriers in relation to accessing human rights for, among others, women, racial minorities, children, and people with disabilities. A new system would need to reflect the principles of nondiscrimination, inclusion, and participation as well as account for diversity in a way that ensures meaningful_as opposed to superficial-coverage of the rights of all persons. 